\title{
Zebrafish Get Connected: Investigating Neurotransmission Targets and Alterations in Chemical Toxicity
}

\author{
Katharine A. Horzmann and Jennifer L. Freeman * \\ School of Health Sciences, Purdue University, West Lafayette, IN 47907, USA; khorzmann@purdue.edu \\ * Correspondence: jfreema@purdue.edu; Tel.: +1-765-494-1408 \\ Academic Editor: Robert Tanguay \\ Received: 1 July 2016; Accepted: 9 August 2016; Published: 27 August 2016
}

\begin{abstract}
Neurotransmission is the basis of neuronal communication and is critical for normal brain development, behavior, learning, and memory. Exposure to drugs and chemicals can alter neurotransmission, often through unknown pathways and mechanisms. The zebrafish (Danio rerio) model system is increasingly being used to study the brain and chemical neurotoxicity. In this review, the major neurotransmitter systems, including glutamate, GABA, dopamine, norepinephrine, serotonin, acetylcholine, histamine, and glutamate are surveyed and pathways of synthesis, transport, metabolism, and action are examined. Differences between human and zebrafish neurochemical pathways are highlighted. We also review techniques for evaluating neurological function, including the measurement of neurotransmitter levels, assessment of gene expression through transcriptomic analysis, and the recording of neurobehavior. Finally examples of chemical toxicity studies evaluating alterations in neurotransmitter systems in the zebrafish model are reviewed.
\end{abstract}

Keywords: acetylcholine; dopamine; GABA; glutamate; neurotoxicology; neurotransmission; neurotransmitters; norepinephrine; serotonin; zebrafish

\section{Introduction}

Neurotransmission is the basis of neuronal communication and is critical for normal brain development, behavior, learning and memory, and even maintenance of life. The nervous system is exceedingly complex, and many enzymes, transporters, and receptors all work in concert to maintain these functions. Neurotransmission can be altered by exposure to drugs, pharmaceuticals, chemotherapeutic agents, radiation, food additives, and environmental toxicants including pesticides and heavy metals $([1,2]$ and as reviewed by [3-6]). Alterations in neurotransmission have been linked to a number of diseases including movement disorders, neuropsychiatric disorders, and depression (reviewed by [7-9]).

The zebrafish (Danio rerio) research model is increasingly being used in neurotoxicity studies (as reviewed by [3,10-13]). Zebrafish share the common neurotransmitter pathways with mammals and have similar neuroanatomy in many areas such as the spinal cord, hindbrain and retina, but as the brain develops by eversion rather than inversion, some classical regions of the mammalian brain, such as the hippocampus, amygdala, and substantia nigra, are not present as such in zebrafish. The function of these areas appears to be maintained elsewhere in the brain, allowing functional comparisons between zebrafish and mammals [14]. As an additional resource, Mueller and Wullimann have recently published a second edition of their "Atlas of Early Zebrafish Brain Development", which characterizes neuronal development and provides excellent figure panels for neuroanatomy [15].

Although the neurochemistry of zebrafish has been reviewed previously $[11,16]$, this review will specifically focus on reviewing the application of the zebrafish in chemical toxicology studies 
investigating adverse impacts to neurotransmitter systems. In addition, this review includes new research findings published since the last reviews on zebrafish neurochemistry, updated terminology, and aims to serve as a reference for the major neurotransmitter systems.

\section{Zebrafish as a Biomedical Model}

The zebrafish is a well-recognized biomedical research model. Zebrafish have been utilized in many scientific disciplines including developmental biology, drug discovery, pharmacology, genetics, and toxicology (reviewed in [17-20]). The zebrafish has many strengths as a research model. The adults are small (up to $3 \mathrm{~cm}$ ), and large colonies can be easily maintained with basic husbandry. Zebrafish have a short generational interval, with sexual maturity beginning at 3-4 months post fertilization (mpf). Once mature, a single breeding pair of zebrafish can produce 100-200 fertilized embryos per spawning. The embryos develop ex utero, are nearly transparent, and are easily manipulated for developmental studies [21,22]. Zebrafish are also ideal for genetic manipulation, with ex utero fertilization allowing for the production of haploid embryos [23].

The zebrafish genome has been mapped and approximately $70 \%-80 \%$ of zebrafish genes share homology with the human genome, and $84 \%$ of genes associated with disease in humans are also present in zebrafish [24,25]. Furthermore, metabolic pathways are highly conserved between zebrafish and mammals, making zebrafish well suited to mechanism focused research [18].

The early teleost had a whole-genome duplication event approximately 320-350 million years ago [26,27]. Although nearly half of these gene duplicates are thought to have been lost within the first 75 million years, it is hypothesized that the remaining genes may have undergone a process of subfunctionalization or neofunctionalization [28,29]. Genes with a single copy in zebrafish are referred to as being orthologs to human genes if they share a common gene origin, while genes with two copies in zebrafish are termed paralogous and may have sub- or neofunctionalization [30]. The teleost whole-genome duplication event has important implications for the study of gene functions in biological pathways, including the neurotransmitter systems where two paralogs may have divergent functions.

\section{Review of Neurotransmitter Systems}

Zebrafish share the common neurotransmitter systems with other vertebrates, and therefore can serve as a model system for neurotoxicity. Although there are many more similarities than not, there are some noteworthy differences between mammals and zebrafish within the neurotransmitter systems, mainly in the number and name of genes encoding proteins, as a result of the teleost gene duplication event. In general, the synthesis and metabolism pathways are shared between the brain of mammals and teleosts. The major shared neurotransmitter systems are reviewed and differences in relevant genes, anatomy, and physiology are highlighted below.

\subsection{Glutamate}

Glutamate is the most common neurotransmitter in the mammalian and teleost brain, with an expected $80 \%-90 \%$ of mammalian synapses using glutamate as the neurotransmitter [31]. Glutamate is the primary excitatory neurotransmitter with functions associated with neurodevelopment, learning and memory, and general cognition as well as neurodegenerative diseases and pathologic conditions such as epilepsy, amnesia, cerebral ischemia, motor neuron diseases, pain, and psychosis [32,33]. Glutamate is also associated with synaptic plasticity and, depending on the receptor activated, may act to modulate neural impulses received by the postsynaptic neuron rather than excite [34,35].

Glutamate, an amino acid, is a member of multiple metabolic pathways including the tricarboxylic acid (TCA) cycle and is a precursor of many biologically important molecules including amino acids L-proline and L-arginine as well as the neurotransmitter $\gamma$-aminobutyric acid (GABA) and glutathione $[33,36]$. Most of the glutamate within the brain is produced from $\alpha$-ketoglutarate, an intermediate of the TCA cycle. $\alpha$-ketoglutarate is transaminated with another amino group, 
usually from aspartate, to form glutamate. This transamination is typically performed by aspartate aminotransferase, an enzymatic protein encoded by the glutamic-oxaloacetic transaminase 1 (GOT1) gene; however, other aminotransferases such as glutamic-pyruvate transaminases (GPT) can also produce glutamate [36].

Within neurons, the majority of glutamate is stored in synaptic vesicles. In mammals, the solute carrier (SLC) family SLC17 members SLC17A7, SLC17A6, and SLC17A8 (also known as the vesicular glutamate transporter family (VGLUT) 1, 2, 3, respectively) are responsible for transporting glutamate into synaptic vesicles, although only SLC17A7 and SLC17A6 are found in glutamatergic neurons [37]. Once released into the synaptic cleft, glutamate binds to receptors on postsynaptic neurons and adjacent glial cells. Most glutamate receptors are located on the dendritic spines of the postsynaptic neurons [38].

Glutamate receptors fall into two categories, ionotropic and metabotropic. Ionotropic receptors act by opening a cation channel after binding to the target and are thus part of the ligand-gated ion channel superfamily. The ligand-gated ion channel superfamily includes the ionotropic glutamate receptors, $\mathrm{GABA}_{\mathrm{A}}$ receptors, 5-hydroxytryptamine 3 receptor (5-HT3), nicotinic acetylcholine receptors, and glycine receptors as reviewed by Collingridge et al. and Keramidas et al. [39,40]. The superfamily shares a common structure, with each channel being composed of 5 identical or homologous subunits surrounding the central pore [41]. Each subunit has an extensive extracellular, hydrophilic $N$-terminus, 4 transmembrane domains that form the ion channel, and an extracellular C-terminus. The superfamily can be divided into subfamilies which include the ionotropic glutamate receptors, the cys-loop receptor family, and ATP-gated channels. As reviewed by Connolly and Wafford [42] and Kozuska and Paulsen [43], the cys-loop receptor family is characterized by a loop on the $N$-terminus formed by a disulfide bond between two cysteines and includes the $\mathrm{GABA}_{\mathrm{A}}, 5-\mathrm{HT} 3$, nicotinic acetylcholine, and glycine receptors. Each class of ligand-gated ion channels can be further divided based on if the channel is anion or cation specific, with glycine and $\mathrm{GABA}_{\mathrm{A}}$ receptors being anionic and 5-HT3 and nicotinic acetylcholine receptors being cationic for example [40].

Metabotropic receptors act through second messenger systems. The term metabotropic is typically applied to a family of glutamate receptors that are G-protein-coupled receptors; however, $\mathrm{GABA}_{\mathrm{B}}$ receptors, catecholamine receptors, all serotonin receptors except for 5- $\mathrm{HT}_{3}$, muscarinic acetylcholine receptors, and histamine receptors also act through second messenger systems and can be classified as metabotropic receptors due to their activation of $G$ proteins and a variety of intracellular signaling cascades upon target binding [44-46]. As reviewed by Katritch et al., G-protein-coupled receptors have a shared structure with seven transmembrane domains and represent the largest superfamily of proteins [47]. A full description of G-protein-coupled receptors is beyond the scope of this review, but the topic has been extensively reviewed previously $[48,49]$ and is commonly found in textbooks.

The functions, pharmacology, and mechanisms of the glutamate receptor types have been extensively reviewed [33-35,37,50-52]; key information is summarized here.

Ionotropic glutamate receptors are grouped into three classes: $N$-methyl D-aspartate (NMDA), $\alpha$-amino-3-hydroxy-5-methyl-4-isoxazole propionic acid (AMPA), and kainite (KA). The classes were named according to selective agonists and each class is made up of multiple gene families which code for individual receptor subunits. The NMDA class receptor has seven genes which code for glutamate ionotropic receptor NMDA type subunits (GRIN, also known as glutamatergic ionotropic NDMA type; GLuNs): GRIN1, GRIN2A, GRIN2B, GRIN2C, GRIN2D, GRIN3A, and GRIN3B. AMPA receptors are made up of the glutamate ionotropic receptor AMPA type subunits (GRIA, also known as glutamatergic ionotropic AMPA type; GluA), GRIA1, GRIA2, GRIA3, and GRIA4, while glutamate ionotropic receptor kainate type subunits (GRIK, also known as glutamatergic ionotropic kainate type receptors; GluKs) fall into 5 families, GRIK1, GRIK2, GRIK3, GRIK4, and GRIK5 [52,53]. Upon binding glutamate, AMPA and KA receptors rapidly open ion channels that favor sodium conductance, while NMDA channels favor calcium conductance and have slower kinetics [51,52]. 
Metabotropic receptors are organized into three classes or groups, Group I, Group II, and Group III receptors. Group I receptors include GRM1 and GRM5. Group I receptors classically are coupled to $\mathrm{G}_{\mathrm{q}} / \mathrm{G}_{11}$ proteins that activate inositol triphosphate (IP3) second messenger signaling and increase intracellular calcium levels, leading to postsynaptic depolarization [34]. Additional signaling pathways have also been recognized, with Group I receptors also acting through other $G_{q}$ proteins, $G_{i} / o$ proteins, $\mathrm{G}_{\mathrm{s}}$ proteins, and independent of $\mathrm{G}$ proteins to activate alternative pathways. Downstream targets include phospholipase $\mathrm{D}$, and protein kinase pathways such as Jun kinase, the mitogen-activated protein kinase/extracellular receptor kinase (MAPK/ERK) pathway, and the mammalian target of rapamycin (MTOR)/p70 S6 kinase pathway [54-57]. Group II receptors include the GRM2 and GRM3 subtypes and couple predominantly through $G_{i} / G_{o}$ proteins. These proteins act by decreasing $3^{\prime}, 5^{\prime}$-cyclic adenosine monophosphate (cAMP) levels through the inhibition of adenylyl cyclase, resulting in a hyperpolarization of the postsynaptic membranes [34]. Group III receptors are the GRM4, GRM6, GRM7, and GRM8 families and they also act by inhibiting adenylyl cyclase and decreasing intracellular cAMP levels. Group II and Group III members can also act through alternative signaling, similar to Group I receptors $[50,58,59]$.

Glutamate is also taken up into glia and neurons via the SLC1A family of genes, also known as the high affinity excitatory amino acid transporters (EAATs). This gene family regulates the levels of extracellular glutamate to prevent excitotoxicity. In astrocytes and oligodendroglia, glutamate can be used in the TCA cycle for the production of energy, used for protein synthesis, or cycled back to glutamine. Glutamate-ammonia ligase (GLUL; glutamine synthetase) causes waste ammonia to react with glutamate to form glutamine, thus detoxifying the ammonia in the process. Glutamine is exported out of the glial cells into the extracellular fluid by SN/SA transporters in the SLC38 class (also known as SNATs) of solute transporters [53]. The free extracellular glutamine can then be taken back into neurons. Within neurons, phosphate-active glutaminase (GLS or PAG) recycles the glutamine to glutamate once again. Much of the glutamate within the brain is recycled through this glutamine cycle. Glutamate can be further processed into GABA via glutamate decarboxylase in GABAergic neurons.

Table 1 outlines human genes important for glutamatergic synthesis, metabolism, and signaling and known zebrafish paralogs. In most cases, zebrafish have multiple paralogs for each human gene; however, some genes in zebrafish only have a single ortholog. For example, zebrafish express got 1 (glutamic-oxaloacetic transaminase 1), the ortholog of GOT1, while there are two paralogs each of the vesicular glutamate transporters SLC17A7 and SLC17A6 (slc17a7a and slc17a7b, and slc17a6a and slc17a6b, respectively), with only one ortholog of SLC17A8 (slc17a8). Zebrafish have three paralogs of glutamate-ammonia ligase GLUL (glula, glulb, and glulc) and two paralogs of glutaminase GLS ( $g l s a$ and $g l s b$ ) [60]. Zebrafish have 8 paralogous genes that code for AMPA type receptor subunits, 6 genes that code for KA type subunits, and 13 putative genes that code for NMDA type ionotropic receptors [61-63]. Humans have 8 subtypes of metabotropic receptors divided into three groups while zebrafish have 12 receptor subtypes similarly divided [64,65]. Currently there are 13 members of the slc1a family of EAATs transporters, with slc1a8a, slc1a8b, and slc1a9 lacking corresponding paralogs in mammals due to a gene loss event by therian mammals [66,67].

Table 1. Zebrafish genes involved in glutamate neurotransmission.

\begin{tabular}{cccccc}
\hline Common Name & Human & Zebrafish & Gene ID & RefSeq & ZFIN ID \\
\hline $\begin{array}{c}\text { Glutamic-oxaloacetic } \\
\text { transaminase 1 }\end{array}$ & GOT1 & got1 & 406330 & NM_213057 & ZDB-GENE-040426-2003 \\
\hline $\begin{array}{c}\text { Vesicular glutamate } \\
\text { transporter 1 (VGLUT1) }\end{array}$ & SLC17A7 & $\begin{array}{c}\text { slc17a7a } \\
\text { slc17a7b }\end{array}$ & $\begin{array}{c}795293 \\
100331980\end{array}$ & $\begin{array}{c}\text { NM_001098755 } \\
\text { XM_009297642 }\end{array}$ & $\begin{array}{c}\text { ZDB-GENE-050105-5 } \\
\text { ZDB-GENE-131125-32 }\end{array}$ \\
\hline $\begin{array}{c}\text { Vesicular glutamate } \\
\text { transporter 2 (VGLUT2) }\end{array}$ & SLC17A6 & $\begin{array}{l}\text { slc17a6a } \\
\text { slc17a6b }\end{array}$ & $\begin{array}{c}494492 \\
100149756\end{array}$ & NM_001009982 & ZDB-GENE-050105-4 \\
\hline $\begin{array}{c}\text { Vesicular glutamate } \\
\text { transporter 3 (VGLUT3) }\end{array}$ & SLC17A8 & slc17a8 & 5601128821 & ZDB-GENE-030616-554 \\
\hline
\end{tabular}


Table 1. Cont.

\begin{tabular}{|c|c|c|c|c|c|}
\hline Common Name & Human & Zebrafish & Gene ID & RefSeq & ZFIN ID \\
\hline \multirow{3}{*}{$\begin{array}{c}\text { Glutamate-ammonia } \\
\text { ligase (Glutamine } \\
\text { synthetase) }\end{array}$} & \multirow{3}{*}{ GLUL } & glula & 100000775 & NM_181559 & ZDB-GENE-030131-688 \\
\hline & & glulb & 336473 & NM_182866 & ZDB-GENE-030131-8417 \\
\hline & & glulc & 566165 & NM_001075114 & ZDB-GENE-060929-540 \\
\hline \multirow{2}{*}{ Glutaminase } & \multirow{2}{*}{ GLS } & glsa & 564147 & NM_001045044 & ZDB-GENE-050204-3 \\
\hline & & glsb & 564746 & XM_688079 & ZDB-GENE-030616-550 \\
\hline \multicolumn{6}{|l|}{ Ionotropic Reptors } \\
\hline \multirow{8}{*}{ AMPA Receptors } & \multirow[b]{2}{*}{ GRIA1 } & gria1a & 798689 & NM_205598 & ZDB-GENE-020125-1 \\
\hline & & gria1b & 403044 & NM_205730 & ZDB-GENE-020125-2 \\
\hline & \multirow[b]{2}{*}{ GRIA2 } & gria $2 a$ & 170450 & NM_131894 & ZDB-GENE-020125-3 \\
\hline & & gria $2 b$ & 170451 & NM_131895 & ZDB-GENE-020125-4 \\
\hline & \multirow{2}{*}{ GRIA3 } & gria3a & 170452 & NM_198339 & ZDB-GENE-020125-5 \\
\hline & & gria $3 b$ & 368416 & NM_198360 & ZDB-GENE-030616-53 \\
\hline & \multirow{2}{*}{ GRIA4 } & gria $4 a$ & 407735 & NM_214806 & ZDB-GENE-020125-7 \\
\hline & & gria $4 b$ & 336069 & NM_212752 & ZDB-GENE-030131-8013 \\
\hline \multirow{6}{*}{ Kainate Receptors } & \multirow[b]{2}{*}{ GRIK1 } & grik1a & 798001 & XM_009305317 & ZDB-GENE-030131-6502 \\
\hline & & grik1b & 561540 & XM_684948 & ZDB-GENE-070821-1 \\
\hline & GRIK2 & grik2 & 556013 & XM_009300832 & ZDB-GENE-080414-1 \\
\hline & GRIK3 & grik3 & 100334689 & XM_009300849.1 & - \\
\hline & GRIK4 & grik4 & 556582 & XM_009291736 & ZDB-GENE-070821-5 \\
\hline & GRIK5 & grik5 & 798791 & NM_001328156 & ZDB-GENE-070821-6 \\
\hline \multirow{13}{*}{ NMDA Receptors } & \multirow{2}{*}{ GRIN1 } & grin1a & 767745 & NM_001076714 & ZDB-GENE-051202-1 \\
\hline & & grin $1 b$ & 100005675 & NM_001144131 & ZDB-GENE-051202-2 \\
\hline & \multirow{2}{*}{ GRIN2A } & grin2aa & 563297 & XM__686662 & ZDB-GENE-070424-129 \\
\hline & & grin $2 a b$ & 570493 & XM_009306215 & ZDB-GENE-070424-223 \\
\hline & \multirow{2}{*}{ GRIN2B } & grin $2 b a$ & - & - & ZDB-GENE-090821-2 \\
\hline & & grin $2 b b$ & 559976 & NM_001128337 & ZDB-GENE-061207-27 \\
\hline & & grin $2 \mathrm{ca}$ & 100003342 & XM_002661129 & ZDB-GENE-070822-3 \\
\hline & GRIN2C & grin $2 c b$ & 100333648 & XM_009306796 & ZDB-GENE-100308-2 \\
\hline & & grin $2 d a$ & 449864 & XM_009294079 & ZDB-GENE-041008-124 \\
\hline & GRIN2D & $\operatorname{grin} 2 d b$ & - & - & ZDB-GENE-100920-7 \\
\hline & & grin $3 a$ & 564832 & XM_009305086 & ZDB-GENE-130530-780 \\
\hline & GRIN3A & grin $3 b a$ & 566411 & XM_009298558 & ZDB-GENE-070912-354 \\
\hline & GRIN3B & grin $3 b b$ & 100333101 & XM_009305920 & ZDB-GENE-131122-77 \\
\hline Metabotropic Receptors & & & & & \\
\hline & & grm1a & 555576 & NM_001044788 & ZDB-GENE-030131-7893 \\
\hline & GRM1 & grm1b & 100150246 & NM_001302252 & ZDB-GENE-090821-3 \\
\hline Group 1 & & grm5a & 568406 & NM_001328710 & ZDB-GENE-090821-9 \\
\hline & GRM5 & grm5b & 100332913 & NM_001302238 & ZDB-GENE-090821-6 \\
\hline & & grm $2 a$ & 336153 & NM_001302225 & ZDB-GENE-030131-8097 \\
\hline Group II & GRM2 & $g r m 2 b$ & 564461 & NM_001287547 & ZDB-GENE-060201-5 \\
\hline & GRM3 & grm3 & 565256 & NM_001128343 & ZDB-GENE-061009-13 \\
\hline & GRM4 & grm4 & 567181 & NM_001302241 & ZDB-GENE-030131-5781 \\
\hline & & grm $6 a$ & 568484 & NM_001123292 & ZDB-GENE-060208-1 \\
\hline Groun III & GRM6 & grm $6 b$ & 565450 & NM_001080020 & ZDB-GENE-021120-2 \\
\hline Group III & GRM7 & $*$ & - & - & - \\
\hline & & grm8a & 792371 & NM_001302228 & ZDB-GENE-110421-2 \\
\hline & GRM8 & grm $8 b$ & 569768 & NM_001287539 & ZDB-GENE-110421-3 \\
\hline & SLC1A1 & slc1a1 & 436939 & NM_001002666 & ZDB-GENE-040718-414 \\
\hline & & $\operatorname{slc} 1 a 2 a$ & 560802 & NM_001190305 & ZDB-GENE-100422-11 \\
\hline & SLC1A2 & $s l c 1 a 2 b$ & 335836 & NM_199979 & ZDB-GENE-030131-7779 \\
\hline & & $\operatorname{slc} 1 a 3 a$ & 323439 & NM_212640 & ZDB-GENE-030131-2159 \\
\hline & SLC1A3 & $s l c 1 a 3 b$ & 556181 & NM_001190303 & ZDB-GENE-090708-3 \\
\hline & SLC1A4 & slc1a4 & 368885 & NM_001002513 & ZDB-GENE-030616-566 \\
\hline Glutamate Transporters & SLC1A5 & slc1a5 & 100002129 & NM_001190755 & ZDB-GENE-070501-4 \\
\hline & SLC1A6 & slc1a6 & 559270 & NM_001109703 & ZDB-GENE-071004-45 \\
\hline & & slc1a7a & 100170783 & NM_001291344 & ZDB-GENE-061009-24 \\
\hline & SCL1A7 & $s l c 1 a 7 b$ & 100463517 & NM_001190760 & ZDB-GENE-101111-7 \\
\hline & & slc1a8a & 570702 & XM_694211 & ZDB-GENE-101111-8 \\
\hline & SLC1A8 & slc1a8b & 564474 & NM_001190816 & ZDB-GENE-070912-552 \\
\hline & SLC1A9 & slc1a9 & 100463516 & NM_001190759 & ZDB-GENE-101111-9 \\
\hline
\end{tabular}

* Zebrafish $g r m 2 b$ has previously been known as grm7.

During embryonic and post embryonic neurogenesis, proneural and neuronal cells express genes coding for basic helix-loop-helix (Bhlh) transcription factors and the patterns of expression can help identify neuronal populations [68]. The expression of neurogenin 1 (Neurog1)/Neurogenic differentiation 1 (Neurod; NeuroD1) has been linked to the development of glutamatergic neurons [69].

Identification of glutamatergic neurons in adult brains is often made based on the presence of transporter proteins. The SLC17A (VGLUT) genes SLC17A6 and SLC17A7 are often used as markers of 
glutamatergic neurons; however, glial cells can also express these transporters [33,70,71]. Glutamate itself is a poor marker due to its role in many metabolic pathways. Although the various receptor subunits are differentially expressed throughout the brain, glutamate receptors are also expressed on glia [72]. For a further account on distribution of these receptors in zebrafish please see Haug et al. [64] and Huang et al. [65].

\section{2. $G A B A$}

GABA is the major inhibitory neurotransmitter in the central nervous system (CNS) and GABAergic neurons are widely present throughout the brain. As an inhibitory neurotransmitter, GABA mainly acts to modulate neural systems and the activity of postsynaptic cells [73]. GABA has been associated with the regulation of neural transmission and perturbances in the GABAergic system have been associated with epilepsy, depression, schizophrenia, and sleep dysfunction [74-76].

As reviewed by Ben-Ari and Reynolds et al. [77,78], in early development neurons have higher intracellular levels of chloride than mature neurons due to the expression of the sodium-potassium-chloride cotransporter 1 (NKCC1; SLC12A2) in the absence of potassium-chloride cotransporter 2 (KCC2; SLC12A5) expression [79]. Therefore, the classic inhibitory neurotransmitters GABA and glycine act to depolarize, and excite the immature neuron. Concurrent with neuronal maturation, SLC12A5 is expressed and this transporter reverses the chloride gradient, establishing the adult chloride gradient and causing GABA and glycine to act as inhibitory neurotransmitters [80].

GABA is synthesized in neurons through the GABA shunt. In the first step, $\alpha$-ketoglutarate from the TCA cycle is transaminated by the 4 -aminobutyrate transaminase (ABAT; GABA $\alpha$-ketoglutarate transaminase; GABA-T) enzyme into L-glutamic acid. In the second step, glutamate decarboxylase (GAD) removes the carboxyl group and produces GABA. In mammals, two genes code for GAD, $G A D 1$ and $G A D 2$ (also known as $G A D_{67}$ and $G A D_{65}$, respectively) [81].

GABA is packaged into synaptic vesicles by the SLC32A1 solute carrier, also known as Vesicular GABA transporter (VGAT). Upon presynaptic depolarization, the vesicles are released into the synaptic space. SLC6A family members, SLC6A1, SLC6A11, and SLC6A12, also known as GABA transporters (GAT1, GAT3, and BGT1) are responsible for transporting GABA out of the synapse [82]. SLC6A13 (GAT2) does not appear to have a significant role in the brain [73]. Neurons may recycle the collected GABA back into synaptic vesicles or GABA can be metabolized to succinic semialdehyde by ABAT [83]. In glia, which lack GAD, the succinic semialdehyde is oxidized by succinic semialdehyde dehydrogenase (SSADH; aldehyde dehydrogenase 5 family member A1; ALDH5A) into succinic acid, which enters the TCA cycle and can be cycled through to $\alpha$-ketoglutarate to again produce glutamine $[73,84]$.

GABA has two classes of receptors: $\mathrm{GABA}_{\mathrm{A}}$ and $\mathrm{GABA}_{\mathrm{B}}$. As mentioned previously, $\mathrm{GABA}_{\mathrm{A}}$ receptors are ligand-gated ion channel receptors and mediate postsynaptic membrane hyperpolarization through the influx of chloride through their integral channel [85]. Like all ligand-gated ion channels, $\mathrm{GABA}_{\mathrm{A}}$ receptors are pentamers and 19 subunits in 7 classes provide basis of the regional variations and differential actions [86].

$\mathrm{GABA}_{\mathrm{B}}$ receptors are metabotropic and therefore can mediate a variety of effects through their coupling with $G$ proteins [87-89]. GABA $_{B}$ receptors can activate certain potassium channels, regulate IP3, or inhibit cAMP production [89]. Presynaptic GABA receptors may inhibit presynaptic neurotransmitter release [90]. Two $\mathrm{GABA}_{B}$ receptor subunits have been identified in mammals, GABABR1 and GABABR2 (reviewed in $[87,91]$ ).

Table 2 list genes important for the synthesis, metabolism, and action of GABAergic neurons in humans and the known zebrafish paralogs. Zebrafish have a single copy of some GABAergic genes, such as the transaminase abat, the VGAT transporter slc32a1, and aldh5a1 (SSADH). Other genes such as gad1 (glutamate decarboxylase), slc6a1 (GAT1), and slc6a11 (GAT3) have two zebrafish paralogs [92]. Corresponding zebrafish orthologs or paralogs have not been identified for all human GABA receptor 
subunits (e.g., GABRA2 and GABRA4), but some human genes have more than one paralog in zebrafish (e.g., GABBR1: gabbr1a and gabbr1b).

Table 2. Zebrafish genes involved in GABA neurotransmission.

\begin{tabular}{|c|c|c|c|c|c|}
\hline Common Name & Human & Zebrafish & Gene ID & RefSeq & ZFIN ID \\
\hline Na-K-Cl cotransporter 1 (NKCC1) & SLC12A2 & slc12a2 & 415170 & NM_001002080 & ZDB-GENE-040625-53 \\
\hline $\mathrm{K}-\mathrm{Cl}$ cotransporter 2 (KCC1) & SLC12A5 & slc12a5 & 797331 & NM_001302243 & ZDB-GENE-120927-3 \\
\hline 4-aminobutyrate transaminase & $A B A T$ & abat & 378968 & NM_201498 & ZDB-GENE-031006-4 \\
\hline Glutamate decarboxylase & $\begin{array}{l}\text { GAD1 } \\
\text { GAD2 }\end{array}$ & $\begin{array}{l}\operatorname{gad1a} \\
\operatorname{gad} 1 b \\
\operatorname{gad} 2\end{array}$ & $\begin{array}{l}100329827 \\
378441 \\
550403\end{array}$ & $\begin{array}{c}\text { XM_005167412 } \\
\text { NM_194419 } \\
\text { NM_001017708 }\end{array}$ & $\begin{array}{c}\text { ZDB-GENE-070912-472 } \\
\text { ZDB-GENE-030909-3 } \\
\text { ZDB-GENE-030909-9 }\end{array}$ \\
\hline $\begin{array}{l}\text { Vesicular GABA transporter } \\
\text { (VGAT) }\end{array}$ & $S L C 32 A$ & slc32a1 & 798575 & NM_001080701 & ZDB-GENE-061201-1 \\
\hline GABA Transporter 1 (GAT1) & SLC6A1 & $\begin{array}{l}\text { slc6a1a } \\
\text { slc6a1b } \\
\text { slc6a1l }\end{array}$ & $\begin{array}{l}692318 \\
492490 \\
568985\end{array}$ & $\begin{array}{c}\text { NM_001045287 } \\
\text { NM_001007362 } \\
\text { XM_692346 }\end{array}$ & $\begin{array}{l}\text { ZDB-GENE-060519-23 } \\
\text { ZDB-GENE-041114-57 } \\
\text { ZDB-GENE-041210-296 }\end{array}$ \\
\hline GABA Transporter 3 (GAT3) & SLC6A11 & $\begin{array}{l}\text { slc } 6 a 11 a \\
\text { slc } 6 a 11 b\end{array}$ & $\begin{array}{c}558960 \\
100150472\end{array}$ & $\begin{array}{l}\text { NM_001098387 } \\
\text { XM_001919885 }\end{array}$ & $\begin{array}{c}\text { ZDB-GENE-030131-3729 } \\
\text { ZDB-GENE-121116-2 }\end{array}$ \\
\hline $\begin{array}{l}\text { Succinic semialdehyde } \\
\text { dehydrogenase }\end{array}$ & $A L D H 5 A$ & aldh $5 a 1$ & 565235 & NM_001110468 & ZDB-GENE-070228-2 \\
\hline \multicolumn{6}{|l|}{ GABA Receptors } \\
\hline GABA $_{A}$ Receptor Subunit $\alpha$ & $\begin{array}{l}\text { GABRA1 } \\
\text { GABRA2 } \\
\text { GABRA3 } \\
\text { GABRA4 } \\
\text { GABRA5 } \\
\text { GABRA6 }\end{array}$ & $\begin{array}{c}\text { gabra1 } \\
\text { gabra2 } \\
\text { gabra3 } \\
- \\
\text { gabra5 } \\
\text { gabra6a } \\
\text { gabra6b }\end{array}$ & $\begin{array}{c}768183 \\
100150704 \\
100538116 \\
- \\
799124 \\
393704 \\
559693 \\
\end{array}$ & $\begin{array}{c}\text { NM_001077326 } \\
\text { XM_009307207 } \\
\text { XM_009295708 } \\
- \\
\text { XM_001339475 } \\
\text { NM_200731 } \\
\text { XM_002667357 }\end{array}$ & $\begin{array}{c}\text { ZDB-GENE-061013-194 } \\
\text { ZDB-GENE-141216-16 } \\
\text { ZDB-GENE-091204-365 } \\
- \\
\text { ZDB-GENE-081104-30 } \\
\text { ZDB-GENE-040426-1692 } \\
\text { ZDB-GENE-080815-1 }\end{array}$ \\
\hline $\mathrm{GABA}_{\mathrm{A}}$ Receptor Subunit $\beta$ & $\begin{array}{l}\text { GABRB1 } \\
\text { GABRB2 } \\
\text { GABRB3 } \\
-\end{array}$ & $\begin{array}{l}\text { gabrb1 } \\
\text { gabrb2 } \\
\text { gabrb2l } \\
\text { gabrb3 } \\
\text { gabrb4 }\end{array}$ & $\begin{array}{c}100331377 \\
336252 \\
100332196 \\
566922 \\
566514\end{array}$ & $\begin{array}{c}\text { XM_002664133 } \\
\text { NM_001024387 } \\
\text { XM_005174450 } \\
\text { XM_005166079 } \\
\text { XM_005173874XM_017353011 }\end{array}$ & $\begin{array}{c}\text { ZDB-GENE-090313-230 } \\
\text { ZDB-GENE-030131-8196 } \\
\text { ZDB-GENE-111215-5 } \\
\text { ZDB-GENE-101102-2 } \\
\text { ZDB-GENE-070424-211 }\end{array}$ \\
\hline $\mathrm{GABA}_{\mathrm{A}}$ Receptor Subunit $\gamma$ & $\begin{array}{l}\text { GABRG1 } \\
\text { GABRG2 } \\
\text { GABRG3 }\end{array}$ & $\begin{array}{l}- \\
\text { gabrg2 } \\
\text { gabrg3 }\end{array}$ & $\begin{array}{c}- \\
553402 \\
567057\end{array}$ & $\begin{array}{l}- \\
\text { NM_001256250 } \\
\text { XM_009302568 }\end{array}$ & $\begin{array}{c}- \\
\text { ZDB-GENE-091118-65 } \\
\text { ZDB-GENE-070718-5 }\end{array}$ \\
\hline GABA $_{\mathrm{A}}$ Receptor Subunit $\delta$ & GARBD & gabrd & 571422 & XM_695007 & ZDB-GENE-081105-170 \\
\hline GABA $_{\mathrm{A}}$ Receptor Subunit $\pi$ & GABRP & gabrp & 566633 & XM_005173293 & ZDB-GENE-081028-62 \\
\hline GABA $_{\mathrm{A}}$ Receptor Subunit $\rho$ & $\begin{array}{l}\text { GABRR1 } \\
\text { GABR2 } \\
\text { GABR3 }\end{array}$ & $\begin{array}{l}\text { gabrr1 } \\
\text { gabrr } 2 a \\
\text { gabrr } 2 b \\
\text { gabrr } 3 a \\
\text { gabrr } 3 b\end{array}$ & $\begin{array}{c}568984 \\
751659 \\
569032 \\
570876 \\
-\end{array}$ & $\begin{array}{c}\text { NM_001025553 } \\
\text { NM_001045376 } \\
\text { XM_692394 } \\
\text { NM_001128760 } \\
-\end{array}$ & $\begin{array}{c}\text { ZDB-GENE-040724-212 } \\
\text { ZDB-GENE-060825-164 } \\
\text { ZDB-GENE-041014-174 } \\
\text { ZDB-GENE-080722-20 } \\
\text { ZDB-GENE-131120-131 }\end{array}$ \\
\hline GABA $_{\mathrm{A}}$ Receptor Subunit $\zeta$ & GABRZ & gabrz & 561738 & NM_001114742 & ZDB-GENE-080303-26 \\
\hline $\mathrm{GABA}_{\mathrm{B}}$ Receptor 1 & GABBR1 & $\begin{array}{l}\text { gabbr1a } \\
\text { gabbr1b }\end{array}$ & $\begin{array}{l}373873 \\
558708\end{array}$ & $\begin{array}{c}\text { XM_689405 } \\
\text { XM_005170102 }\end{array}$ & $\begin{array}{l}\text { ZDB-GENE-030904-5 } \\
\text { ZDB-GENE-060503-5 }\end{array}$ \\
\hline $\mathrm{GABA}_{\mathrm{B}}$ Receptor 2 & GABBR2 & gabbr2 & 560267 & NM_001144043 & ZDB-GENE-060503-620 \\
\hline
\end{tabular}

GAD has only been identified in GABAergic neurons, therefore providing a specific marker for GABA producing neurons. Additionally, zebrafish achaete-scute homolog 1a (Zash1a) expression has been linked to the development of GABA producing, inhibitory neurons, and has been used as a marker for GABAergic neurons during development $[93,94]$.

In zebrafish, GABA is widely produced in the brain and spinal cord by interneurons [95]. The postembryonic ( 3 days post fertilization; $\mathrm{dpf}$ ) subpallium, preoptic region, ventral and sections of the dorsal thalamus, and hypothalamus have been shown to produce GABA [93]. In the adult, GABA has been identified in the olfactory bulb, subpallium, preoptic, pretectal, ventral thalamic, hypothalamic, and posterior tubercular nuclei with scattered Gad1 positive cells in the pallial zones and the bed nucleus of the stria medullaris [96,97]. GABA, Gad2, Gabra1, and Gabbr1 are expressed in the zebrafish cerebellum and have a similar distribution to mammals [98]. 


\subsection{Catecholamines}

Dopamine, norepinephrine (noradrenaline), and epinephrine (adrenaline) are the major catecholamine neurotransmitters. Structurally, this group is characterized by a catechol group (benzene group with two adjacent hydroxyl groups), with an ethylamine side chain and an amine group. Catecholamines are considered modulatory neurotransmitters and have been linked to reward, movement, memory, and neuropsychiatric disorders [99-101].

Catecholamines are formed from the amino acid tyrosine and oxygen. Tyrosine hydroxylase (tyrosine 3-monooxygenase; TH) is the first enzyme in the synthesis pathway and is the rate limiting step. TH produces 3,4-dihydroxyl-l-phenylalanine (L-DOPA) with (6R)-L-erythro-tetrahydrobiopterin (BH4) and $\mathrm{Fe}^{2+}$ acting as cofactors in the hydroxylase step [102]. L-DOPA is converted to dopamine (DA) by the enzyme aromatic amino acid decarboxylase (AAAD), also known as DOPA decarboxylase [103]. AAAD is the preferred enzyme name as AAAD is also important in the monoamine serotonin synthesis pathway [82]. Although TH immunoreactivity is considered specific for dopaminergic neurons, AAAD can be found in non-monoamine producing neurons and glial cells. AAAD can also alternatively produce trace amines such as tryptamine, tyramine, and 2-phenylethylamine [104].

In noradrenergic and adrenergic neurons $\mathrm{DA}$ is converted to norepinephrine (NE) by dopamine- $\beta$-hydroxylase (dopamine $\beta$-monooxygenase; $\mathrm{DBH}$ ) and $\mathrm{NE}$ can be further modified by phenylethanolamine- $N$-methyltransferase (PNMT) to epinephrine (EP).

Catecholamines are transported into vesicles through members of the SLC18 family, namely SLC18A2 (also known as VMAT2) in the brain (as reviewed by $[105,106])$. SLC18A2 can transport serotonin and histamine as well as catecholamines. Dopamine and norepinephrine transporters belong to the SLC6 family of carriers, with, at least in mammals, SLC6A2 functioning as the norepinephrine transporter (NET), and SLC6A3 as the dopamine transporter (DAT) [107].

Catecholamines are metabolized by a monoamine oxidase (MAO) enzyme. In humans, there are two isoforms of MAO in mammals, MAO-A and MAO-B, with different substrate specificity, pharmacology, and anatomic localization [108]. The catecholamine substrates are degraded into aldehydes, and aldehyde dehydrogenase and aldehyde reductase further degrade the products into alcohols or glycols respectively. Catechol-O-methyltransferase (COMT) adds a methyl group to catecholamines and their metabolites, which assists in elimination of the neurotransmitters and their metabolites. A major DA metabolite is 3,4-dihydroxyphenylacetic acid (DOPAC), which is the product of MAO and aldehyde dehydrogenase. DOPAC can be further metabolized by COMT to form homovanillic acid (HVA). Norepinephrine is mostly metabolized by MAO and aldehyde reductase, forming 3,4-dihydroxyphenylglycol (DHPG). Likewise, DHPG can be further metabolized to 3-methoxy-4-hydroxyphenylgylcol (MHPG) [104].

Catecholamines bind to G-protein-coupled receptors to modulate neurotransmission. As reviewed by Callier et al., there are five dopaminergic receptors in mammals: D1-D5, with D1 and D5 (D1-like) and D2-D4 (D2-like) sharing similar mechanisms [109]. D1-like receptors classically activate $\mathrm{G}_{\mathrm{s}}$ G-proteins causing an increase in cAMP while D2-like activate $G \alpha_{i} / G_{0}$ G-proteins which inhibits adenylyl cyclase activity [110]. Beaulieu et al. extensively reviewed the mechanisms of dopamine receptor signaling [111]. Norepinephrine has nine receptors organized into three families, $\alpha_{1}, \alpha_{2}$, and $\beta$, each containing three receptors. $\alpha_{1}$ receptors activate $G_{q} / G_{11}$ proteins and activate phospholipase $C$ and increase intra cellular calcium and protein kinase $C$ activation. The $\alpha_{2}$ adrenergic receptors are coupled to $G_{i} / G_{0}$ proteins and inhibit adenylyl cyclase and stimulate phospholipase $A 2$. The $\beta$ adrenergic receptors are coupled to $G_{s}$ and activate adenylyl cyclase [104].

Originally two Th encoding paralogs were identified in teleosts, th1 and th2 [112]. th1-negative, th2-positive neurons were identified in zebrafish brain [113-115] and although these neurons appeared to be immunoreactive for slc18a2 (vmat2), aaad, and slc6a3 (dat), consistent with a dopaminergic phenotype, it was discovered that the gene encoded by th2 appears to function as a tryptophan hydroxylase when isolated in vitro $[115,116]$. Therefore, th1 is referred to as th by the Zebrafish 
Information Network (ZFIN) and is considered the only tyrosine hydroxylase in zebrafish. Currently, only one ortholog of $A A A D$ (aaad), DBH (dbh), and of the transporters SLC18A2 (slc18a2), SLC6A2 (slc6a2), and SLC6A3 (slc6a3) have been identified. Although mammals have two isozymes, MAO-A and MAO-B, zebrafish have only one paralogous enzyme, Mao (also known as Zmao) [117]. Zebrafish Mao may have a structure and function more similar to MAO-A, but is inhibited by deprenyl, a MAO-B specific inhibitor [118,119]. Two putative COMT genes have been identified, comta and comtb. However, the gene products have not been fully characterized, and some protein products may not be functional [16,120]. Table 3 outlines known paralogs of dopamine and adrenergic receptors [121,122]. The receptor genes $d r d 1 a$ and $d r d 1 b$ likely have D1-like activity and the other receptor genes likely have D2-like functions [122].

Table 3. Zebrafish genes involved in catecholamine neurotransmission.

\begin{tabular}{|c|c|c|c|c|c|}
\hline Common Name & Human & Zebrafish & Gene ID & RefSeq & ZFIN ID \\
\hline Aromatic amino acid decarboxylase & $A A A D$ & aaad & 406651 & NM_213342 & ZDB-GENE-040426-2656 \\
\hline Phenylethanolamine- $N$-methyltransferase & PNMT & pnmt & 100332609 & XM_002666341 & - \\
\hline $\begin{array}{l}\text { Vesicular monoamine transporter } 2 \\
\text { (VMAT2) }\end{array}$ & SLC18A2 & slc18a2 & 553304 & NM_001256225 & ZDB-GENE-080514-1 \\
\hline Dopamine transporter (DAT) & SLC6A3 & slc $6 a 3$ & 80787 & NM_131755 & ZDB-GENE-010316-1 \\
\hline Norepinephrine transporter (NET) & SLC6A2 & slc $6 a 2$ & 565776 & XM_689046 & ZDB-GENE-110408-4 \\
\hline Catechol-O-methyltransferase & COMT & $\begin{array}{l}\text { comta } \\
\text { comtb }\end{array}$ & $\begin{array}{l}561372 \\
565370\end{array}$ & $\begin{array}{l}\text { NM_001030157 } \\
\text { NM_001083843 }\end{array}$ & $\begin{array}{l}\text { ZDB-GENE-050913-117 } \\
\text { ZDB-GENE-040724-164 }\end{array}$ \\
\hline Dopamine Receptors & $\begin{array}{l}\text { DRD1 } \\
\text { DRD2 } \\
\text { DRD3 } \\
\text { DRD4 } \\
\text { DRD5 }\end{array}$ & $\begin{array}{l}d r d 1 a \\
d r d 1 b \\
d r d 2 a \\
d r d 2 b \\
d r d 2 l \\
d r d 3 \\
d r d 4 a \\
d r d 4 b \\
d r d 5 a \\
d r d 5 b\end{array}$ & $\begin{array}{c}792634 \\
568126 \\
282557 \\
378719 \\
378718 \\
282554 \\
503564 \\
503565 \\
100536970 \\
-\end{array}$ & $\begin{array}{c}\text { XM_017359120 } \\
\text { NM_001135976 } \\
\text { NM_183068 } \\
\text { NM_197936 } \\
\text { NM_197935 } \\
\text { NM_183067 } \\
\text { NM_001012616 } \\
\text { NM_001012618 } \\
\text { XM_003199767 } \\
-\end{array}$ & $\begin{array}{c}\text { ZDB-GENE-130522-1 } \\
\text { ZDB-GENE-070524-2 } \\
\text { ZDB-GENE-021119-2 } \\
\text { ZDB-GENE-030910-2 } \\
\text { ZDB-GENE-030910-1 } \\
\text { ZDB-GENE-021119-1 } \\
\text { ZDB-GENE-070112-996 } \\
\text { ZDB-GENE-070508-3 } \\
\text { ZDB-GENE-130522-2 } \\
\text { ZDB-GENE-130522-3 }\end{array}$ \\
\hline Adrenergic Receptors & $\begin{array}{l}\text { ADRA1A } \\
\text { ADRA1B } \\
\text { ADRA1D } \\
\text { ADRA2 } \\
\text { ADRA2B } \\
\text { ADRA2C } \\
\text { ADRB1 } \\
\text { ADRB2 } \\
\text { ADRB3 }\end{array}$ & $\begin{array}{l}\text { adra1aa } \\
a d r a 1 a b \\
a d r a 1 b a \\
a d r a 1 b b \\
\text { adra1d } \\
\text { adra } 2 a \\
\text { adra } 2 b \\
a d r a 2 c \\
a d r a 2 d a \\
a d r a 2 d b \\
a d r b 1 \\
a d r b 2 a \\
a d r b 2 b \\
a d r b 3 a \\
a d r b 3 b\end{array}$ & $\begin{array}{c}798498 \\
557259 \\
100149100 \\
492486 \\
568614 \\
266750 \\
266751 \\
266752 \\
266754 \\
266755 \\
557194 \\
565838 \\
100037315 \\
558248 \\
792519\end{array}$ & $\begin{array}{c}\text { NM_001324454 } \\
\text { XM_680297 } \\
\text { XM_001921978 } \\
\text { NM_001007358 } \\
\text { XM_691951 } \\
\text { NM_207637 } \\
\text { NM_207638 } \\
\text { NM_207639 } \\
\text { NM_194364 } \\
\text { NM_194365 } \\
\text { NM_001128689 } \\
\text { NM_001102652 } \\
\text { NM_001089471 } \\
\text { NM_001128335 } \\
\text { NM_001135134 }\end{array}$ & $\begin{array}{c}\text { ZDB-GENE-030131-2831 } \\
\text { ZDB-GENE-060503-384 } \\
\text { ZDB-GENE-120510-1 } \\
\text { ZDB-GENE-041114-51 } \\
\text { ZDB-GENE-090312-203 } \\
\text { ZDB-GENE-021010-1 } \\
\text { ZDB-GENE-021010-2 } \\
\text { ZDB-GENE-021010-3 } \\
\text { ZDB-GENE-021010-4 } \\
\text { ZDB-GENE-021010-5 } \\
\text { ZDB-GENE-081022-145 } \\
\text { ZDB-GENE-100414-3 } \\
\text { ZDB-GENE-070410-32 } \\
\text { ZDB-GENE-080917-21 } \\
\text { ZDB-GENE-081022-154 }\end{array}$ \\
\hline
\end{tabular}

In order to help compare neuroanatomy between species, dopaminergic populations have been labeled numerically based on rostral to caudal location in the brain. As reviewed by Schweitzer et al. [123], Rink and Wullimann [124] labeled the dopaminergic populations 1-8 in larvae and 0-8 in adults, with 0 representing the ventral thalamic area. Sallinen [119] used a 17 population classification scheme. Both classification systems localize dopaminergic neurons to the olfactory bulb, subpallium, posterior tuberculum, hypothalamus, and pretectum [123]. Zebrafish brain lack a substantia nigra and ventral tegmental area, however, the posterior tuberculum has populations of dopaminergic cells with projections that extend to the subpallium and spinal cord $[125,126]$. Figure 1 outlines the locations of the modulatory neurotransmitters in humans and zebrafish. 
Zebrafish

A

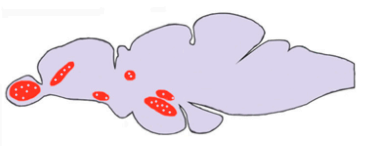

B

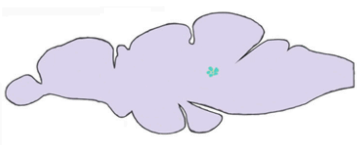

C

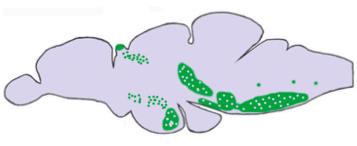

D

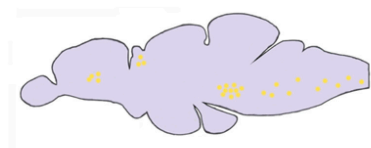

E

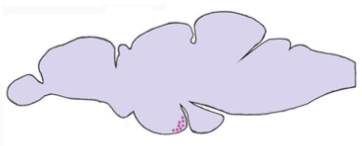

Human
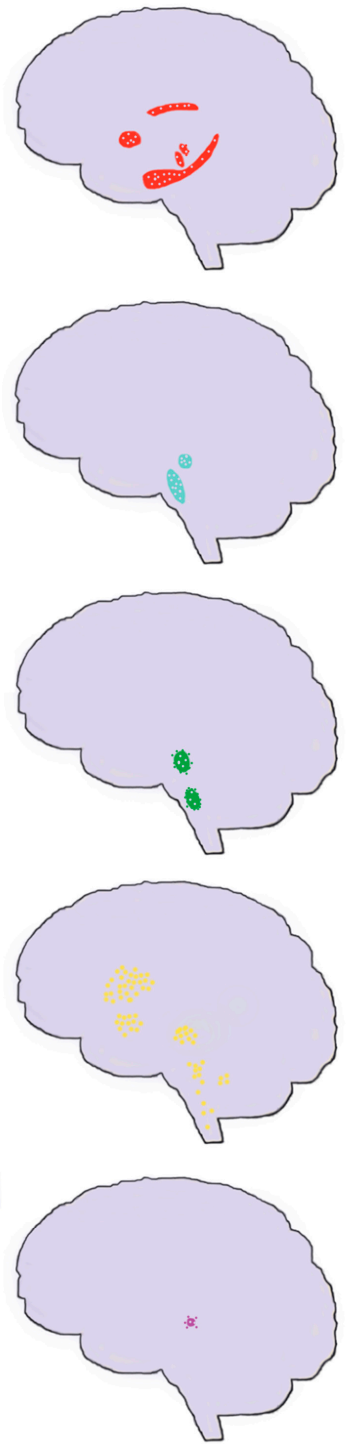

Figure 1. Distribution of Modulatory Neurotransmitters in the Zebrafish and Human Brain. (A) Distribution of DA in the zebrafish (left) and human (right) brains (red); (B) Distribution of NE in zebrafish (left) and human (right) brains (blue); (C) Distribution of 5-HT in zebrafish (left) and human (right) brains (green); (D) Distribution of ACh in zebrafish (left) and human (right) brains (yellow); (E) Distribution of histamine in zebrafish (left) and human (right) brains (purple). Brains are not to scale with some simplification of systems that are represented. DA, dopamine; NE, norepinephrine; 5-HT, serotonin; ACh, acetylcholine. Neurotransmitter distributions synthesized from [16,127-133].

Neurons producing dopamine or norepinephrine also produce either glutamate or GABA and therefore have two transmitter profiles. Dopaminergic neurons in the dopaminergic posterior tubercular groups 2, 4, and 6 and hypothalamic group 5 and some norepinephrine producing cells in the area postrema produce glutamate and all other dopamine or norepinephrine producing neurons produce GABA [134].

$\mathrm{DBH}$, the enzyme that converts dopamine to epinephrine, is also present and is used as a marker of adrenergic neurons. Dbh is only found in zebrafish hindbrain, specifically at the locus coeruleus $[135,136]$. The locus coeruleus projects to the pallium, the subpallium and the thalamus [137,138]. 


\subsection{Serotonin}

The neurotransmitter serotonin (5-hydroxytrptamine; 5-HT) is a biologic amine. 5-HT has an indole nucleus with a hydroxyl group and an amine group. L-tryptophan is the base of the molecule, with dietary protein being the major source. 5-HT is a modulatory neurotransmitter and has been associated with brain development, appetite, motor function, arousal and mood, neuroendocrine function, circadian rhythms, and depression [139-142].

The first enzyme in the 5-HT synthesis pathway is tryptophan hydroxylase (L-tryptophan-5monooxygenase; TPH), which converts tryptophan to 5-hydroxytryptophan (5-HTP). The conversion of tryptophan to 5-HTP is considered the rate limiting step in the synthesis pathway and is unique to serotonergic neurons. In mammals there are two genes that code for TPH. TPH1 is expressed in the periphery and $\mathrm{TPH} 2$ is expressed exclusively in the brain and can be used as a marker for serotonergic neurons [143]. Once formed, 5-HTP is quickly converted to 5-HT by AAAD.

5-HT is transported into synaptic vesicles by vesicular transporter SLC18A2 (VMAT2) and released from the vesicle via exocytosis [144]. The serotonin transporter SLCl6A4 (also known as SERT) is responsible for the uptake/reuptake of 5-HT, although glia and non-serotonergic neurons can take up serotonin through organic cation transporter (OCT), plasma membrane monoamine transporter (PMAT), or through SLC6A2 or SLC6A3 (NET and DAT, respectively) [145].

5-HT is metabolized by MAO to 5-hydroxy-indolecetaldehyde which is rapidly metabolized by an aldehyde dehydrogenase to form 5-hydroxyindoleacetic acid (5-HIAA), the major metabolite of 5-HT [145].

In mammals there are three families of 5-HT receptors (HTR) that act through G-proteins, the 5- $\mathrm{HT}_{1}$ family, the $5-\mathrm{HT}_{2}$ family, and a family that includes the $5-\mathrm{HT}_{4}, 5-\mathrm{HT}_{6}$, and 5- $\mathrm{HT}_{7}$ receptors [142]. $5-\mathrm{HT}_{3}$ is a cation specific ligand-gated ion channel and is considered its own family [145]. The 5-HTR family generally acts to inhibit adenylyl cyclase through the $\mathrm{G}_{\mathrm{i} / \mathrm{o}}$ family of $\mathrm{G}$ proteins while the $5-\mathrm{HTR}_{2}$ family acts through $\mathrm{G}_{\mathrm{q} / 11}$ family $\mathrm{G}$ proteins by stimulating phospholipase $\mathrm{C}$. The 5-HTR, $5-\mathrm{HTR}_{6}$, and 5-HTR 7 family mainly act through the $\mathrm{G}_{\mathrm{s}}$ family $\mathrm{G}$ proteins to stimulate adenylyl cyclase [146].

As a result of the teleost gene duplication event, zebrafish have four paralogous genes encoding $\mathrm{TPH}$, although the nomenclature has not been standardized. Bellipanni et al. first identified two paralogs of TPH in the developing zebrafish brain, $t p h D 1$, expressed in the preoptic nuclei and the posterior tubercular in the diencephalon, and $t p h D 2$, expressed in the pineal gland and transiently in the preoptic nuclei [147]. Teraoka et al. identified a third paralog of Tph, tphR, expressed in the raphe nuclei and pineal gland [148]. In later reviews of the serotonin neurotransmitter system, these genes are referred to as $t p h 1 a, t p h 1 b$, and $t p h 2$, respectively [149-151]. Further research found that zebrafish th2 encodes for a fourth tph gene in the ventral diencephalon and caudal hypothalamus [116]. This gene has also been called tph3 to better reflect its function [150]. As mentioned previously, zebrafish have only one ortholog of $A A A D$ and $M A O$ [117]. There are two paralogs of the serotonin transporter gene $S L C 6 A 4$, slc6a4a and slc6a4b [152]. In mammals, over 15 HTR genes have been identified. Table 4 outlines the critical genes in serotonin synthesis and metabolism as well as listing known paralogous genes for the serotonin HTR receptor families [121].

Table 4. Zebrafish genes involved in serotonin neurotransmission.

\begin{tabular}{cccccc}
\hline Common Name & Human & Zebrafish & Gene ID & RefSeq & ZFIN ID \\
\hline Tryptophan hydroxylase & TPH1 & $\begin{array}{c}t p h 1 a \\
t p h 1 b \\
t p h 2 \\
t p h 3 / t h 2\end{array}$ & $\begin{array}{c}352943 \\
415103 \\
407712 \\
414844\end{array}$ & $\begin{array}{c}\text { NM_001001843 } \\
\text { NM_001310068 } \\
\text { NM_001001829 }\end{array}$ & $\begin{array}{c}\text { ZDB-GENE-030317-1 } \\
\text { ZDB-GENE-030805-6 } \\
\text { ZDB-GENE-040624-4 } \\
\text { ZDB-GENE-050201-1 }\end{array}$ \\
\hline $\begin{array}{c}\text { Aromatic amino acid } \\
\text { decarboxylase }\end{array}$ & TPH2 & aaad & 406651 & NM_212827 & ZDB-GENE-040426-2656 \\
\hline Monoamine oxidase & MAO-A & mao & 404730 & NM_001039972 & ZDB-GENE-040329-3 \\
\hline Serotonin Transporter (SERT) & SLC6A4 & $\begin{array}{l}\text { slc6a4a } \\
\text { slc6a4b }\end{array}$ & $\begin{array}{l}664719 \\
664770\end{array}$ & $\begin{array}{c}\text { NM_001177459 } \\
\text { NM_001123321 }\end{array}$ & ZDB-GENE-060314-1 \\
ZDB-GENE-060314-2
\end{tabular}


Table 4. Cont.

\begin{tabular}{|c|c|c|c|c|c|}
\hline Common Name & Human & Zebrafish & Gene ID & RefSeq & ZFIN ID \\
\hline \multirow{15}{*}{ Serotonin Receptors } & \multirow{2}{*}{ HTR1A } & htr1aa & 100001828 & NM_001145766 & ZDB-GENE-071203-1 \\
\hline & & $h+r 1 a b$ & 797538 & NM_001128709 & ZDB-GENE-090409-2 \\
\hline & \multirow[t]{3}{*}{ HTR1B } & $h t r 1 b$ & 561647 & NM_001145686 & ZDB-GENE-081022-141 \\
\hline & & htr1d & 556429 & NM_001145686 & ZDB-GENE-090409-3 \\
\hline & & htr1fa & 100005344 & XM_017357893 & ZDB-GENE-081105-125 \\
\hline & \multirow{2}{*}{ HTR2 } & $h+r 2 a$ & 560808 & NM_001044743 & ZDB-GENE-070912-500 \\
\hline & & $h t r 2 b$ & 751784 & NM_001044743 & ZDB-GENE-081022-57 \\
\hline & HTR2CL1 & $h t r 2 c l 1$ & 100000981 & XM_001339004 & ZDB-GENE-081104-48 \\
\hline & HTR2CL2 & $h t r 2 c l 2$ & 798599 & XM_001339004 & ZDB-GENE-120215-109 \\
\hline & \multirow{2}{*}{ HTR3 } & htr3a & 571641 & XM_009295409 & ZDB-GENE-071012-5 \\
\hline & & $h t r 3 b$ & 571632 & NM_001126410 & ZDB-GENE-071012-4 \\
\hline & HTR5 & $h t r 5 a$ & 100038775 & NM_001007121 & ZDB-GENE-060531-129 \\
\hline & HTR5-like & htr5al & 368475 & XM_009297078 & ZDB-GENE-030616-574 \\
\hline & HTR6 & htr6 & 568269 & X⿳亠丷厂二_685507 & ZDB-GENE-030131-7839 \\
\hline & HTR7 & $h+r 7$ & 562111 & NM_178306 & ZDB-GENE-130530-666 \\
\hline
\end{tabular}

As reviewed by Lillesaar [149], in larval zebrafish 5-HT positive cells are located in the pineal gland, the pretectum, the posterior tuberculum, the hypothalamus, and the superior and inferior raphe. Panula et al. outlined a labeling scheme for the adult zebrafish with serotoninergic nuclei identified in the pretectal complex, the anterior, intermediate, and posterior paraventricular organ nuclei, the dorsal, median, and ventrolateral raphe, the inferior raphe, and the caudal raphe $[16,150]$. Adult zebrafish also have scattered serotonergic neurons within the medulla oblongata [137]. The distribution of 5-HT in the zebrafish brain compared to humans is shown in Figure 1C.

When identifying serotonergic populations, the Ets-domain transcription factor pet1 (pheochromocytoma 12 ETS [E26 transformation-specific]) is a specific developmental marker of the raphe serotonergic nuclei [151]. TPH is typically used as the serotonergic specific marker in imaging studies [149].

\subsection{Acetylcholine}

Acetylcholine (ACh) is the major neurotransmitter in the parasympathetic nervous system and is the neurotransmitter at neuromuscular junctions [153]. Additionally, ACh neurotransmission is widespread in the CNS and can help modulate the release of other neurotransmitters such as GABA, and has been implicated in arousal, reward, and learning and memory [153-155].

ACh is formed from acetyl-CoA and choline via choline acetyltransferase (ChAT). Two SLC family transport systems, a high affinity (SLC5A7; HAChU) and a low affinity (SLC44 family; LAChU), concentrate choline in terminals to provide a reserve for ACh synthesis. SLC44 is present ubiquitously throughout the body, but SLC5A7 is only found in cholinergic nerve termini [156]. The rate of SLC5A7 transport is regulated by the rate of ACh release and SLC5A7 is the rate limiting step in ACh production. Once ACh has been synthesized by ChAT it is packaged into vesicles by vesicular ACh transporter (VAChT) which is coded by SLC18A3 [106]. ACh is then released in quanta into the synaptic cleft in a calcium dependent manner. Unlike other neurotransmitters which have transporter mediated uptake/reuptake to clear the synapse, ACh is metabolized by acetylcholinesterase (AChE) within the synaptic space and broken into acetate and choline [156].

There are two major types of cholinergic receptors, nicotinic (nAChR) and muscarinic receptors $(\mathrm{mAChR})$. The receptors were respectively named after nicotine and muscarine, their drug agonists. nAChRs are a member of the cys-loop family of ligand-gated ion channel receptors and are formed by combinations of receptor subunits [156,157]. In mammals, there are 17 nicotinic receptor subunits including muscle and neural specific subunits. nAChRs are located throughout the brain, though many subtypes of $\mathrm{nAChR}$ are located on presynaptic termini or cell bodies and function to modulate neurotransmitter release [154]. mAChRs are G-protein-coupled receptors and are located throughout the CNS and PNS. There are five subtypes of $\mathrm{mAChR}$ receptors in mammals, M1-M5. M1, M3, and M5 couple to $\mathrm{G}_{\mathrm{q} / 11}$ family proteins to increase phospholipase $\mathrm{C}$. M2 and M4 receptors act to decrease 
adenylyl cyclase through $\mathrm{G}_{\mathrm{i}} / \mathrm{G}_{\mathrm{o}}$ receptor activation. $\mathrm{mAChR}$ are expressed throughout the brain, but are not uniformly distributed (reviewed by Brown [158]).

The important genes in the cholinergic system are outlined in Table 5. Zebrafish have two paralogs of the HAChU SLC5A7 (slc5a7a and slc5a7b), although slc5a7b has not been well described. The gene that produces ChAT has two paralogs in zebrafish, chata and chatb. slc18a3a and slc18a3b are two paralogs of SLC18A3 (VAChT). There is only one paralog of ACHE (ache). Currently, there are 12 putative genes encoding nAChR subunits in zebrafish and 10 putative paralogs of mAChR [159-161].

Table 5. Zebrafish genes involved in cholinergic neurotransmission.

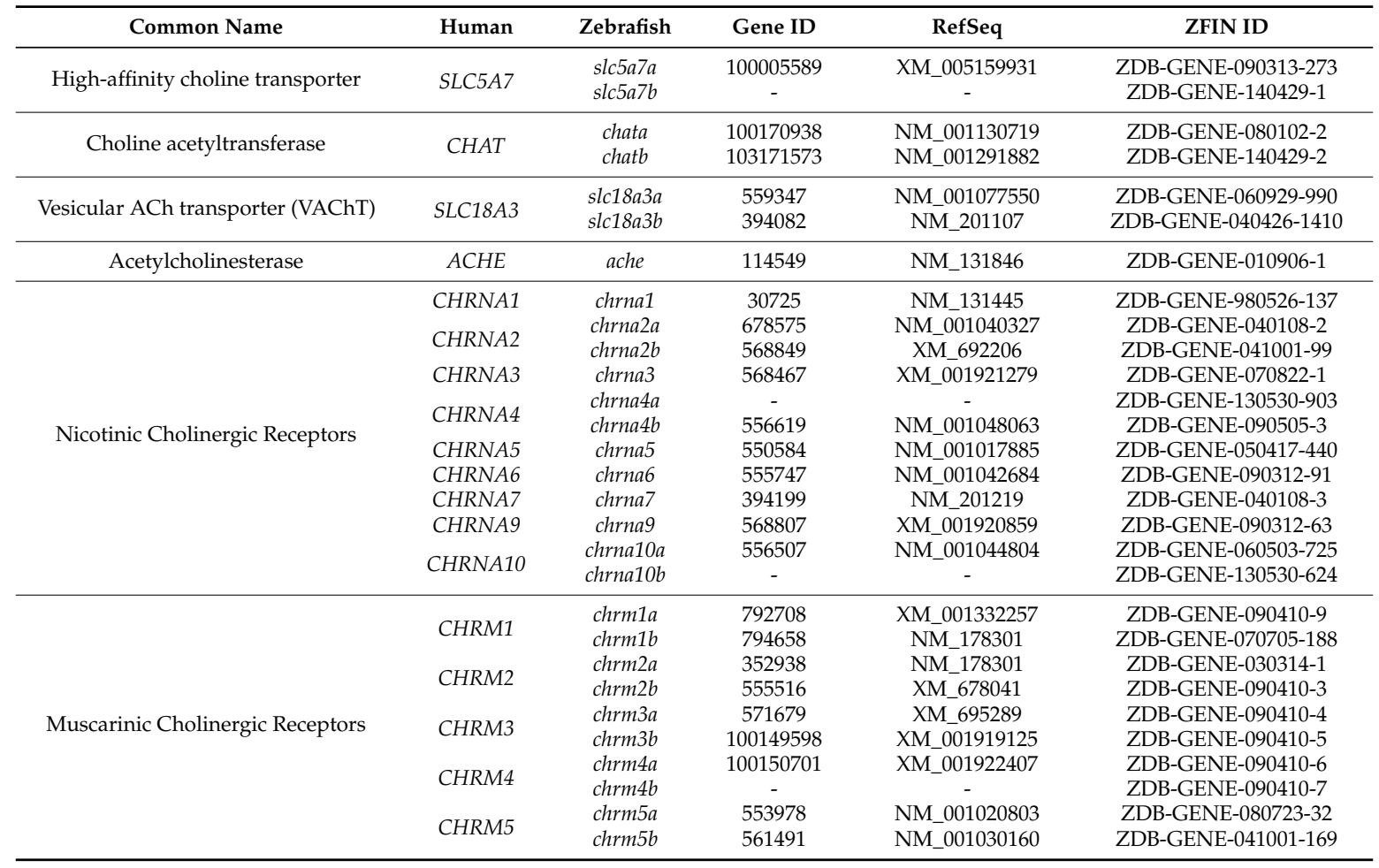

Cholinergic neurons have been identified through immunohistochemical staining against choline-acetyltransferase (ChAT) [94,162]. In zebrafish, cholinergic neurons are found in both the brain and spinal cord, specifically in the octavolateralis cells and modulatory or sensory neurons, the ventral telencephalic area, the central, dorsal, and subcommissural nuclei of the ventral telencephalic areas, the preoptic area, dorsal thalamus, pretectal nuclei, hypothalamus, optic tectum, and tegmentum $[137,163-165]$. The distribution of ACh in zebrafish and human brains is shown in Figure 1D.

\subsection{Histamine}

Histamine is a signaling molecule present in many tissues, serving functions in the stomach, skin, and immune systems. Histamine also has a role in neurotransmission [166]. Within the CNS, histamine is associated with wakefulness, feeding and drinking, and learning and memory $[130,167,168]$.

The structure of histamine, 2-(4-imidazolyl)ethylamine, is similar to 5-HT, NE, and EP, but histamine has an imidazole nucleus and therefore has tautomeric properties that may be associated with receptor affinity. In mammals, mast cells of bone marrow origin reside in perivascular spaces, choroid plexus, and meninges and can produce significant amounts of histamine within the brain although the only neurons that produce histamine are located within hypothalamic tuberomamilary neurons within the posterior hypothalamus [169]. Zebrafish, on the other hand, do not have stores of histamine outside of the brain, suggesting any histamine is of importance to 
neurotransmission [130,170]. The periventricular cells of the caudal hypothalamus are the only cell group that contains histaminergic neurons in zebrafish brain, similar to mammals, although the axons project throughout the CNS $[137,170]$. These histamine producing neurons also contain other signaling molecules including GABA, neuropeptides, and thyrotropin-releasing hormone [171].

Histamine is synthesized by L-histidine decarboxylase (HDC). The rate of biosynthesis is controlled by the availability of L-histidine and the rate limiting enzyme, HDC. Once formed, histamine is transported into vesicles by SLC18A2 (VMAT2) [172]. Most histamine in the brain is released via non-synaptic mechanisms and often acts on both presynaptic and postsynaptic receptors. There is no evidence of a neuronal histamine transporter [169].

The metabolism of histamine can occur either by diamine oxidase (DAO; amine oxidase AOC1), which oxidizes histamine to imidazole acetic acid (IAA), or by histamine $N$-methyltransferase (HNMT), which methylates histamine and forms tele-methylhistamine (t-MH) and is then further metabolized by MAO (MAO-B in mammals) to tele-methylimidazole acetic acid (t-MIAA). The methylation metabolism pathway is more common in vertebrate brains and HMT is widely distributed throughout the brain [168,169].

Mammals have four histamine receptors that are found in the brain, H1, H2, H3, and H4. H1 and $\mathrm{H} 2$ are considered excitatory while $\mathrm{H} 3$ is inhibitory and often acts as an autoreceptor. $\mathrm{H} 4$ is the most recently discovered but does appear to localize to the brain [173]. Histamine receptors are linked to G proteins in both neurons and glia. $\mathrm{H} 1$ receptors are linked to $\mathrm{G}_{\mathrm{q}}$ and stimulate phospholipase $\mathrm{C}$. $\mathrm{H} 2$ receptors may couple with $\mathrm{G}_{\mathrm{q}}$ or $\mathrm{G}_{\mathrm{s}}$ but act through the stimulation of adenylyl cyclase. $\mathrm{H} 3$ receptors are linked to $G_{i / o}$ and inhibit adenylyl cyclase. $H 3$ receptors may also activate MAPK, Akt/GSK-3 $\beta$, and phospholipase $\mathrm{A}_{2}$ pathways [174-176]. The $\mathrm{H} 4$ receptor is similar to the $\mathrm{H} 3$ receptor and acts through $\mathrm{G}_{\mathrm{i} / \mathrm{o}}$ proteins to inhibit adenylyl cyclase [173].

In zebrafish there is one ortholog each of HDC (L-histidine decarboxylase), AOC1 (diamine oxidase), and HNMT (histamine $N$-methyltransferase) (Table 6). To date, there are four known genes in zebrafish that code for histamine receptors, $h r h 1, h r h 2 a, h r h 2 b$, and $h r h 3$ [177]. In zebrafish, histamine containing neurons have been localized only to the ventrocaudal hypothalamus, though the projections are widespread $[137,178]$. The distribution of histamine in the zebrafish brain compared to humans is shown in Figure 1E.

Table 6. Zebrafish genes involved in histamine neurotransmission.

\begin{tabular}{cccccc}
\hline Common Name & Human & Zebrafish & Gene ID & RefSeq & ZFIN ID \\
\hline L-Histidine decarboxylase & $H D C$ & $h d c$ & 793609 & NM_001102593 & ZDB-GENE-080102-5 \\
\hline Amine oxidase & AOC1 & $a \circ 1$ & 555401 & NM_001077598 & ZDB-GENE-061103-112 \\
\hline Histamine $N$-methyltransferase & $H N M T$ & $h n m t$ & 445242 & NM_001003636 & ZDB-GENE-040801-157 \\
\hline \multirow{2}{*}{ Histamine Receptors } & $H R H 1$ & $h r h 1$ & 735302 & NM_001042731 & ZDB-GENE-070531-3 \\
& $H R H 2$ & $h r h 2 a$ & 735303 & NM_001045338 & ZDB-GENE-070531-4 \\
& $H R H 3$ & $h r h 3$ & 100005590 & NM_001109738 & ZDB-GENE-070928-20 \\
& & & 561773 & NM_001025518 & ZDB-GENE-040724-204 \\
\hline
\end{tabular}

\subsection{Glycine}

Glycine is an amino acid that serves as a signaling molecule and neurotransmitter in the brainstem and spinal cord. Glycine is the simplest amino acid, with only a hydrogen for its side chain. Glycine, typically considered an inhibitory neurotransmitter, is involved with interneuron differentiation in neurodevelopment, mediation of spinal reflexes, and reflex behaviors such as breathing [179,180].

Glycine can be formed through the conversion of serine to glycine with either glycine dehydrogenase (GLDC), also known as glycine decarboxylase (GDC) or glycine-cleavage system, or serine hydroxylmethyltransferase (SHMT). Glycine is transported into synaptic vesicles via the vesicular inhibitory amino acid transporter, SLC32A1 (VIAAT, also known as vesicular GABA transporter (VGAT)) [180]. 
Glycine is transported out of the synaptic cleft by glycine transporters. Two glycine transporters, SLC6A9 (GLYT1) and SLC6A5 (GLYT2), have been identified in mammals [180]. SLC6A9 and SLC6A5 transporters are expressed on both astrocytes and postsynaptic neurons [181].

The glycine receptors are in the ligand gated ion channel superfamily. In mammals, glycine receptor subunits arise from two separate gene families. The $\alpha$ gene family has four subunit genes $\left(\alpha_{1}-\alpha_{4}\right)$ and the $\beta$ gene group has only one member (reviewed by Bowery and Smart [182]). Glycine also acts on NMDA receptors and modulates the amplitude and time course of the glutamate-elicited response [183]. Interestingly, although no metabotropic counterparts have been identified, the glycine receptor subunit $\alpha$ can interact with $G$ protein $\beta \gamma$ subunits, which potentiates the response to glycine [184].

As outlined in Table 7, zebrafish tend to have a single known ortholog for most of the genes important for glycine metabolism $[185,186]$. The exception is the presence of two paralogs for glycine receptor $\alpha$ subunit 4 gene and the glycine receptor $\beta$ gene. Glycinergic neurons are identified via positive immunoreactivity for glycine transporter (slc6A9) immunohistochemistry. In the developing zebrafish, glycine producing cells are limited to the hindbrain and spinal cord, and appear as early as $20 \mathrm{~h}$ post fertilization (hpf) $[187,188]$. In adult zebrafish, the vast majority of glycinergic neurons are within the medulla oblongata, though a few positive neurons are within a ventral tegmental equivalent nucleus $[129,187]$.

Table 7. Zebrafish genes involved in glycine neurotransmission.

\begin{tabular}{cccccc}
\hline Common Name & Human & Zebrafish & Gene ID & RefSeq & ZFIN ID \\
\hline Glycine dehydrogenase & GLDC & gldc & 321621 & NM_199554 & ZDB-GENE-030131-340 \\
\hline Serine hydroxymethyltransferase 1 & SHMT1 & shmt1 & 394021 & NM_201046 & ZDB-GENE-040426-1558 \\
\hline Serine hydroxymethyltransferase 2 & SMHT2 & shmt2 & 100144628 & NM_001123374 & ZDB-GENE-071213-1 \\
\hline Inhibitory amino acid transporter & SLC32A1 & slc32a1 & 798575 & NM_001080701 & ZDB-GENE-061201-1 \\
\hline Glycine transporter 1 & SLC6A9 & slc6a9 & 494490 & NM_001030073 & ZDB-GENE-050105-3 \\
\hline Glycine transporter 2 & SLC6A5 & slc6a5 & 494450 & NM_001009557 & ZDB-GENE-050105-2 \\
\hline Glycine receptor $\alpha$ & GLRA1 & glra1 & 30676 & NM_131402 & ZDB-GENE-991117-1 \\
& GLRA2 & glra2 & 793646 & NM_001167899 & ZDB-GENE-090407-1 \\
& GLRA3 & glra3 & 192124 & NM_152965 & ZDB-GENE-020402-1 \\
& GLRA4 & glra4a & 83413 & NM_131782 & ZDB-GENE-010410-3 \\
& glra4b & 192125 & NM_001202511 & ZDB-GENE-020402-2 \\
\hline \multirow{2}{*}{ Glycine receptor $\beta$} & GLRB & glrba & 83412 & NM_131781 & ZDB-GENE-010410-2 \\
& & glrbb & 445193 & NM_001003587 & ZDB-GENE-040801-106 \\
\hline
\end{tabular}

\subsection{Other Neurotransmitters}

Other substances can also act as neurotransmitters in the brain, including purines, peptides, nitric oxide, and endocannabinoids [189,190]. Please see Rico et al. [11] for a review of the purine nucleotides and nucleosides in zebrafish and Panula et al. [16] for a review of neuropeptides.

\section{Evaluation of Neurotoxicity}

The neurotransmitter systems can serve as targets of chemical toxicity. The individual enzymes, transporters, and receptors may be altered by chemical toxicants through changes in gene expression or changes in activity of the enzyme or receptor. Multiple methods can be used to evaluate neurotransmitter systems in zebrafish, from the measuring of neurotransmitter levels in the brain, to evaluation of gene expression, to the functional testing of behavioral assays. These methods are reviewed below.

\subsection{Evaluation of Neurotransmitters}

In the evaluation of chemical toxicants, measuring neurotransmitter levels can provide information on the functional alterations in the brain resulting from chemical treatment. The quantity of neurotransmitters 
can be measured in the zebrafish brain. Sallinen et al. [119] and Chattererjee et al. [191] have both described methods for measuring neurotransmitter levels via high performance liquid chromatography (HPLC) that have been modified and used in other laboratories [192,193].

Experimental neurotransmitter results may be comparable within one laboratory, but not comparable across multiple laboratories due to differences in experimental methods and equipment used. Furthermore, one difficulty in comparing neurotransmitter levels across studies and laboratories is the lack of reference intervals and the tendency to normalize neurotransmitter values to controls rather than reporting absolute values, which limits comparison. For example, Pan et al. [194] reported the difference in neurotransmitter levels between the $\mathrm{AB}$ and short-fin wildtype strains of zebrafish as a ratio between zebrafish strains, rather than average concentration. Table 8 lists reported neurotransmitter levels from control zebrafish. Comparison of values in the table is difficult between studies in part to different methodologies used for normalization. Neurotransmitter levels can be normalized to protein content or number of fish pooled for the sample, and it is difficult to equate between the two methods.

Other methods for the measurement of neurotransmitters include an analytical method described by Tufi et al. [195] of hydrophilic interaction liquid chromatography (HILIC) coupled to tandem mass spectrometry (MS/MS) that has been used to measure neurotransmitter levels in zebrafish larvae. The levels of neurotransmitters and major metabolites were measured in 0-6 dpf zebrafish larvae. Additionally, Jones et al. [196] describe a technique to detect neurotransmitter release and reuptake in brain tissue slices through fast scan cyclic voltammetry (FSCV).

Table 8. Reported neurotransmitter levels in control zebrafish brain.

\begin{tabular}{|c|c|c|c|c|c|c|}
\hline $\begin{array}{l}\text { Reference (Age, } \\
\text { Sex, and Strain if } \\
\text { Known) }\end{array}$ & Glutamate & GABA & DA & NE & 5-HT & ACh \\
\hline \multicolumn{7}{|c|}{ Adult Zebrafish } \\
\hline $\begin{array}{l}\text { López Patiño et al. } \\
\text { [197] } \\
\text { (Male and female } \\
9 \pm 1 \mathrm{mpf} A B \\
\text { wildtype) }\end{array}$ & - & - & $1.5-2 \mathrm{pg} / \mathrm{ug}$ protein & - & - & - \\
\hline $\begin{array}{l}\text { Chatterjee and } \\
\text { Gerlai [191] } \\
\text { (Male and female } \\
90 \mathrm{dpf} \mathrm{AB} \\
\text { wildtype) }\end{array}$ & - & - & $\begin{array}{c}4.18 \pm 0.28 \mathrm{ng} / \mathrm{mg} \\
\text { protein }\end{array}$ & - & - & - \\
\hline \multicolumn{7}{|c|}{ Embryonic/Larval Zebrafish } \\
\hline
\end{tabular}

\subsection{Evaluation of Gene Expression Changes in Neurotransmitter Pathways}

Chemical toxicants can affect the expression of genes, and evaluation of these changes can provide information on pathways that may be altered due to chemical exposure. Quantitative PCR (qPCR) can be used to evaluate alterations in gene expression [198]; however, the information is limited to the number of genes investigated.

Microarray studies have been used to evaluate gene expression after chemical exposure in zebrafish [199-202]. The value of transcriptomic evaluations in zebrafish toxicology studies is well recognized, especially for environmental toxicology [12,203]. Next generation technologies such as RNA-seq are providing precise and powerful options for evaluating the transcriptome [203,204]. Please see the review by Wang et al. [204] and Aanes et al. [205] for information on RNA-seq and its application in zebrafish. 


\subsection{Evaluation of Neurobehavior}

The significance of apparent alterations in gene expression and changes in neurotransmitter levels is uncertain without having differences in phenotype. Zebrafish are an accepted model of neurobehavior [206-215] and have been used to study stress, anxiety-like behavior, and depression, with decreased movement typically associated with anxiety [216-218]. Zebrafish are increasingly being used in neurobehavioral research to evaluate learning and neuropsychiatric disorders (reviewed by $[207,208,212,219])$. Neurobehavioral tests have been developed for both larval and adult zebrafish to assess anxiety-like behavior. Changes in neurobehavior can substantiate changes observed through neurotransmitter analysis or through transcriptomic evaluation; however, changes in neurobehavior cannot be localized to a specific neurotransmitter, pathway, or protein. Please refer to Kalueff et al. [219] and Parker et al. [220] for recent reviews of neurobehavior in zebrafish toxicology research.

\subsection{Visualization of Neurotransmitters and Neurotransmitter Systems}

The visualization of neurotransmitters has been important for evaluating the location, relative quantity, and pathologic alterations of neurotransmitters and neurotransmitter pathway components. A multitude of techniques, including immunohistochemistry, in situ hybridization, immunofluorescence, calcium indicators, selective fluorescent reporters [221-226] (and reviewed by [227]) have been used to study neuroanatomy and neurotransmitter systems in zebrafish. The imaging of neurotransmitters, transporters, and receptors in zebrafish brains has classically been used in the study of developmental biology [68] and recently for neural systems mapping [226,228]. A recent review by Arrenberg and Driever [228] highlights the use of optogenetics and calcium indicator activity probes in the development of functional maps of the zebrafish brain. Currently this methodology has been underused in studies of chemical toxicity, but could provide powerful information when combined with the other approaches mentioned.

\subsection{Pharmacology Screens}

The advantages of the zebrafish model system allow for high throughput screening of pharmacologic agents which can help identify neuropathways, mechanisms of toxicity, possible therapeutic drugs, and help classify zebrafish behavior (reviewed by [229-234]). The neuropharmacology of the monoamine neurotransmitters was reviewed by Maximino and Herculano [235]. Kalueff et al. [219] have also recently written a highly recommended review that evaluates the zebrafish system in neurobehavior and pharmacology screenings.

\section{Specific Examples of Chemical Toxicity Targeting Neurotransmitter Systems}

Zebrafish have been used as a model organism to study the effect of multiple classes of chemicals on neurodevelopment and neural function. Classes of chemicals examined include drugs, especially ethanol, pesticides, and metals. The significant methods and findings from the literature are summarized below and in Table 8 .

\subsection{Drugs}

The effects of alcohol have been extensively studied in zebrafish. Rico et al. [236] found that adult zebrafish exposed to ethanol had increased AChE activity in a 1\% ethanol treatment group although the mRNA levels of AChE were decreased, suggesting post-transcriptional or post-translational modifications to AChE. Chatterjee and Gerlai [191] found that adult zebrafish exposed to ethanol for $1 \mathrm{~h}$ had an increase in brain dopamine levels at all treatment levels, while 5-HT and 5-HIAA increased at the highest (1\%) ethanol group. Chatterjee and Shams [237] found a similar increase in dopamine and 5-HT after acute ethanol exposure in AB strain zebrafish, but not in SF strain zebrafish. Puttonen et al. [238], found that larval Turku strain zebrafish with acute exposure to ethanol had increased locomotor activity at lower treatment levels, decreased locomotor activity 
at the highest treatment level (3\%), upregulation of $h d c$ (histidine decarboxylase), th1, and th2 at higher treatment levels, no alterations in the dopaminergic and histaminergic systems according to in situ hybridization and immunohistochemistry, and a decrease in dopamine levels, as measured by HPLC. These results suggest that ethanol has the ability to alter the cholinergic, dopaminergic, and histaminergic neurotransmitter systems and that neurobehavior can be a sensitive measure of altered neurotransmitter systems.

The effects of alcohol on zebrafish behavior appear to have an inverted U shaped dose-response, with increased locomotor activity and shoaling behavior at lower doses and decreased locomotor activity and shoaling behavior at higher doses, as well as either increased or decreased measures of anxiety [237,239-242]. Although this finding appears to be dependent on the specific zebrafish strain (AB, SF, WIK, or Turku strain) used and therefore, needs further analysis [237-239,243]. Bailey et al. found juvenile $\mathrm{AB}$ strain zebrafish with developmental exposure to ethanol had increased locomotor activity overall and after stress or anxiety inducing stimuli [244]. A latent learning neurobehavioral assay performed by Luchiari et al. suggested that $A B$ strain zebrafish have impaired memory recall after ethanol exposure [245]. Echevarria et al. have reviewed additional behavioral outcomes of ethanol exposure in zebrafish [246].

Zenki et al. [247] found that alcohol and its metabolite acetaldehyde decreased the activity of glutamate transporters, based on measuring the in vitro rate of glutamate uptake in tissue sections, in adult zebrafish and that acetaldehyde was more toxic than ethanol when measuring cell viability via 3(4,5-dimethylthiazol-2-yl)-2,5-diphenyl tetrazolium bromide (MTT) reduction and extracellular lactate dehydrogenase (LDH) activity.

Nicotine is often used to study nicotinic cholinergic receptors, but nicotine also is a drug known for anxiolytic effects. Levin et al. [248] and Bencan and Levin [249], found that adult zebrafish exposed to nicotine had reduced time spent in the bottom of a novel tank (novel tank test) and found that the anxiolytic effect was mediated through the Chrna7 and Chrna4b receptor subunits [248,249]. Levin and Chen (2004), also found that adult zebrafish exposed to low dose nicotine had improved memory based on a 3-chambered tank test for learning assessment while zebrafish exposed to higher concentrations of nicotine had impaired memory function [250].

\subsection{Pesticides}

Pesticides represent a broad group of chemicals that include herbicides, insecticides, fungicides, and rodenticides. Some pesticides are important environmental toxicants while others are more acutely toxic to humans (for example, during application or manufacturing).

The effects of organophosphate pesticides on brain acetylcholinesterase are well known, however, exposure to organophosphates can also affect other brain neurotransmitter systems. Eddins et al. [251] studied the effects of developmental exposure of zebrafish to chlorpyrifos. Adult zebrafish previously exposed to chlorpyrifos had greater startle responses in a startle response and habituation behavioral assay that persisted into the habituation period. Additionally, decreased dopamine and serotonin levels and increased transmitter turnover were measured in larval zebrafish while only the decreased dopamine persisted to adulthood [251].

Atrazine is a commonly used herbicide in the Midwestern United States that often contaminates drinking water supplies. Wirbisky et al. [199] found decreased levels of the serotonin metabolite 5-HIAA and decreased serotonin turnover (5-HIAA/5-HT) in the brain of adult female zebrafish aged 9 months that were exposed to atrazine only during embryogenesis. Transcriptomic analysis via microarray identified multiple molecular pathways related to brain development, function, and behavior that were altered in the treatment groups including several targets associated with the serotoninergic system [199].

Semicarbazide is a contaminant formed from the breakdown of azodicarbonamide, a chemical used to treat flour. Semicarbazide derivatives have also been used as herbicides. Adult zebrafish exposed to semicarbazide for $96 \mathrm{~h}$ had increased expression of gad1 while adult zebrafish with 
28 day exposure had down regulation of gad1, gabrr1, and gabbr2 [252]. Yu et al. [252] suggest the alterations of the GABAergic pathway genes could indirectly result in alterations in the hypothalamus-pituitary-gonadal axis.

Strychnine is commonly used as rodent bait. Roy et al. [253] found that zebrafish embryos treated with strychnine had decreased expression of glra4 at 24 and 48 hpf, gad1 at 24-96 hpf, and slc17a6a and slc17a6b (VGLUT2) at $48 \mathrm{hpf}$.

\subsection{Metals}

Some metals, such as lead and mercury are important environmental toxicants [254-256]. Developmental lead exposure is linked to a number of CNS effects, including lowered IQ and attention deficit disorders [257-260]. Wirbisky et al. [193] found that developmental exposure to lead resulted in altered expression of GABAergic pathway genes including gad2, gad1b, slc6a1 (gat1), slc32a1 (vgat), gabbr1, and gabbr1a as well as altering GABA levels during development. Furthermore, Lee and Freeman [261] found that adult zebrafish with a developmental lead exposure had altered gene expression in pathways associated with neurodevelopment and neurotransmission.

In addition, studies have also started to evaluate the impact of mercury exposure on neurotransmitter systems. The toxicity of mercury depends on its chemical form. Methylmercury is associated with Minamata disease and nervous system impairment. Cambier et al. [198] fed adult male fish food contaminated with methylmercury and found changes in gene expression in the GABA synthesis and metabolism pathways. Inorganic mercury is associated with acute toxicity and renal failure; however, Richetti et al. [262] found that adult zebrafish exposed to mercury chloride and lead acetate had decreased activity of acetylcholinesterase, but no alterations in the gene expression of AChE.

\section{Conclusions}

The neurotransmitter systems are highly conserved between zebrafish and mammals, making the zebrafish model a powerful tool for the study of mechanisms of chemical neurotoxicity. Although there are some differences in neurochemistry, the pathways of neurotransmitter synthesis, metabolism, and action are highly conserved across species. Although some genes have multiple paralogs in zebrafish, further research into these paralogs may help identify new functions of genes in humans. Furthermore, further research into neurotransmitter receptors may provide more information about basic neurological systems and connectivity.

The nervous system is an important target of chemical toxicants. Neurotransmitter levels, gene expression, and neurobehavior can be evaluated after chemical treatment to discover toxicant based changes in the nervous system. New technologies provide more sensitive and powerful methods; however, the integration of these methods along with other techniques, such as imaging and activity assays, will be necessary to determine the mechanisms and pathogenesis of chemical toxicant related alterations. Overall, relatively few studies have focused on alterations of neurochemical systems in zebrafish, but the completed studies support the utility and application of zebrafish in neurochemical toxicology.

Acknowledgments: This work was supported by the National Institutes of Health, National Institute of Environmental Health Sciences (R15 ES019137 to J.L.F.).

Author Contributions: K.A.H. wrote the review with the assistance of J.L.F.

Conflicts of Interest: The authors declare no conflict of interest.

\section{References}

1. Megha, K.; Deshmukh, P.S.; Ravi, A.K.; Tripathi, A.K.; Abegaonkar, M.P.; Banerjee, B.D. Effect of low-intensity microwave radiation on monoamine neurotransmitters and their key regulating enzymes in rat brain. Cell Biochem. Biophys. 2015, 73, 93-100. [CrossRef] [PubMed] 
2. Kaplan, S.V.; Limbocker, R.A.; Gehringer, R.C.; Divis, J.L.; Osterhaus, G.L.; Newby, M.D.; Sofis, M.J.; Jarmolowicz, D.P.; Newman, B.D.; Mathews, T.A.; et al. Impaired brain dopamine and serotonin release and uptake in wistar rats following treatment with carboplatin. ACS Chem. Neurosci. 2016, 7, 689-699. [CrossRef] [PubMed]

3. Parng, C.; Roy, N.M.; Ton, C.; Lin, Y.; McGrath, P. Neurotoxicity assessment using zebrafish. J. Pharmacol. Toxicol. Methods 2007, 55, 103-112. [CrossRef] [PubMed]

4. Andersen, H.R.; Nielsen, J.B.; Grandjean, P. Toxicologic evidence of developmental neurotoxicity of environmental chemicals. Toxicology 2000, 144, 121-127. [CrossRef]

5. Grandjean, P.; Landrigan, P.J. Developmental neurotoxicity of industrial chemicals. Lancet 2006, 368, 2167-2178. [CrossRef]

6. Costa, L.G. Interactions of neurotoxicants with neurotransmitter systems. Toxicology 1988, 49, 359-366. [CrossRef]

7. Beitz, J.M. Parkinson's disease: A review. Front. Biosci. (Sch. Ed.) 2014, 6, 65-74. [CrossRef]

8. Sarter, M.; Bruno, J.P.; Parikh, V. Abnormal neurotransmitter release underlying behavioral and cognitive disorders: Toward concepts of dynamic and function-specific dysregulation. Neuropsychopharmacology 2006, 32, 1452-1461. [CrossRef] [PubMed]

9. Werner, F.M.; Covenas, R. Classical neurotransmitters and neuropeptides involved in major depression: A review. Int. J. Neurosci. 2010, 120, 455-470. [CrossRef] [PubMed]

10. De Esch, C.; Slieker, R.; Wolterbeek, A.; Woutersen, R.; de Groot, D. Zebrafish as potential model for developmental neurotoxicity testing: A mini review. Neurotoxicol. Teratol. 2012, 34, 545-553. [CrossRef] [PubMed]

11. Rico, E.P.; Rosemberg, D.B.; Seibt, K.J.; Capiotti, K.M.; Da Silva, R.S.; Bonan, C.D. Zebrafish neurotransmitter systems as potential pharmacological and toxicological targets. Neurotoxicol. Teratol. 2011, 33, 608-617. [CrossRef] [PubMed]

12. Fan, C.-Y.; Cowden, J.; Simmons, S.O.; Padilla, S.; Ramabhadran, R. Gene expression changes in developing zebrafish as potential markers for rapid developmental neurotoxicity screening. Neurotoxicol. Teratol. 2010, 32, 91-98. [CrossRef] [PubMed]

13. Nishimura, Y.; Murakami, S.; Ashikawa, Y.; Sasagawa, S.; Umemoto, N.; Shimada, Y.; Tanaka, T. Zebrafish as a systems toxicology model for developmental neurotoxicity testing. Congenit. Anom. 2015, 55, 1-16. [CrossRef] [PubMed]

14. Cheng, R.K.; Jesuthasan, S.J.; Penney, T.B. Zebrafish forebrain and temporal conditioning. Philos. Trans. R. Soc. Lond. Ser. B Biol. Sci. 2014, 369, 20120462. [CrossRef] [PubMed]

15. Mueller, T.; Wullimann, M.F. Atlas of Early Zebrafish Brain Development, 2nd ed.; Elsevier: San Diego, CA, USA, 2016.

16. Panula, P.; Chen, Y.C.; Priyadarshini, M.; Kudo, H.; Semenova, S.; Sundvik, M.; Sallinen, V. The comparative neuroanatomy and neurochemistry of zebrafish CNS systems of relevance to human neuropsychiatric diseases. Neurobiol. Dis. 2010, 40, 46-57. [CrossRef] [PubMed]

17. Bowman, T.V.; Zon, L.I. Swimming into the future of drug discovery: In vivo chemical screens in zebrafish. ACS Chem. Biol. 2010, 5, 159-161. [CrossRef] [PubMed]

18. Hill, A.J.; Teraoka, H.; Heideman, W.; Peterson, R.E. Zebrafish as a model vertebrate for investigating chemical toxicity. Toxicol. Sci. 2005, 86, 6-19. [CrossRef] [PubMed]

19. Lele, Z.; Krone, P.H. The zebrafish as a model system in developmental, toxicological and transgenic research. Biotechnol. Adv. 1996, 14, 57-72. [CrossRef]

20. Yang, L.; Ho, N.Y.; Alshut, R.; Legradi, J.; Weiss, C.; Reischl, M.; Mikut, R.; Liebel, U.; Müller, F.; Strähle, U. Zebrafish embryos as models for embryotoxic and teratological effects of chemicals. Reprod. Toxicol. 2009, 28, 245-253. [CrossRef] [PubMed]

21. McGrath, P.; Li, C.-Q. Zebrafish: A predictive model for assessing drug-induced toxicity. Drug Discov. Today 2008, 13, 394-401. [CrossRef] [PubMed]

22. Penberthy, W.T.; Shafizadeh, E.; Lin, S. The zebrafish as a model for human disease. Front. Biosci. 2002, 7, d1439-d1453. [CrossRef] [PubMed]

23. Vascotto, S.G.; Beckham, Y.; Kelly, G.M. The zebrafish's swim to fame as an experimental model in biology. Biochem. Cell Biol. 1997, 75, 479-485. [CrossRef] [PubMed] 
24. Barbazuk, W.B.; Korf, I.; Kadavi, C.; Heyen, J.; Tate, S.; Wun, E.; Bedell, J.A.; McPherson, J.D.; Johnson, S.L. The syntenic relationship of the zebrafish and human genomes. Genome Res. 2000, 10, 1351-1358. [CrossRef] [PubMed]

25. Howe, K.; Clark, M.D.; Torroja, C.F.; Torrance, J.; Berthelot, C.; Muffato, M.; Collins, J.E.; Humphray, S.; McLaren, K.; Matthews, L.; et al. The zebrafish reference genome sequence and its relationship to the human genome. Nature 2013, 496, 498-503. [CrossRef] [PubMed]

26. Vandepoele, K.; De Vos, W.; Taylor, J.S.; Meyer, A.; Van de Peer, Y. Major events in the genome evolution of vertebrates: Paranome age and size differ considerably between ray-finned fishes and land vertebrates. Proc. Natl. Acad. Sci. USA 2004, 101, 1638-1643. [CrossRef] [PubMed]

27. Christoffels, A.; Koh, E.G.; Chia, J.M.; Brenner, S.; Aparicio, S.; Venkatesh, B. Fugu genome analysis provides evidence for a whole-genome duplication early during the evolution of ray-finned fishes. Mol. Biol. Evol. 2004, 21, 1146-1151. [CrossRef] [PubMed]

28. Sato, Y.; Hashiguchi, Y.; Nishida, M. Temporal pattern of loss/persistence of duplicate genes involved in signal transduction and metabolic pathways after teleost-specific genome duplication. BMC Evolut. Biol. 2009, 9, 1-14. [CrossRef] [PubMed]

29. Glasauer, S.M.; Neuhauss, S.C. Whole-genome duplication in teleost fishes and its evolutionary consequences. Mol. Genet. Genom. 2014, 289, 1045-1060. [CrossRef] [PubMed]

30. Postlethwait, J.; Amores, A.; Cresko, W.; Singer, A.; Yan, Y.L. Subfunction partitioning, the teleost radiation and the annotation of the human genome. Trends Genet. 2004, 20, 481-490. [CrossRef] [PubMed]

31. Braitenberg, V.; Schüz, A. Cortex: Statistics and Geometry of Neuronal Connectivity, 2nd ed.; Springer: Berlin, Germang, 1998.

32. Meldrum, B.S. Glutamate as a neurotransmitter in the brain: Review of physiology and pathology. J. Nutr. 2000, 130, 1007s-1015s. [PubMed]

33. Niciu, M.J.; Kelmendi, B.; Sanacora, G. Overview of glutamatergic neurotransmission in the nervous system. Pharmacol. Biochem. Behav. 2012, 100, 656-664. [CrossRef] [PubMed]

34. Sherman, S.M. The function of metabotropic glutamate receptors in thalamus and cortex. Neuroscientist 2014, 20, 136-149. [CrossRef] [PubMed]

35. Zhou, Y.; Danbolt, N.C. Glutamate as a neurotransmitter in the healthy brain. J. Neural Transm. 2014, 121, 799-817. [CrossRef] [PubMed]

36. Yelamanchi, S.D.; Jayaram, S.; Thomas, J.K.; Gundimeda, S.; Khan, A.A.; Singhal, A.; Keshava Prasad, T.S.; Pandey, A.; Somani, B.L.; Gowda, H. A pathway map of glutamate metabolism. J. Cell Commun. Signal. 2016, 10, 69-75. [CrossRef] [PubMed]

37. Fremeau, R.T., Jr.; Voglmaier, S.; Seal, R.P.; Edwards, R.H. Vgluts define subsets of excitatory neurons and suggest novel roles for glutamate. Trends Neurosci. 2004, 27, 98-103. [CrossRef] [PubMed]

38. Rubio, M.E.; Wenthold, R.J. Differential distribution of intracellular glutamate receptors in dendrites. J. Neurosci. 1999, 19, 5549-5562. [PubMed]

39. Collingridge, G.L.; Olsen, R.W.; Peters, J.; Spedding, M. A nomenclature for ligand-gated ion channels. Neuropharmacology 2009, 56, 2-5. [CrossRef] [PubMed]

40. Keramidas, A.; Moorhouse, A.J.; Schofield, P.R.; Barry, P.H. Ligand-gated ion channels: Mechanisms underlying ion selectivity. Prog. Biophys. Mol. Biol. 2004, 86, 161-204. [CrossRef] [PubMed]

41. Howard, R.J.; Trudell, J.R.; Harris, R.A. Seeking structural specificity: Direct modulation of pentameric ligand-gated ion channels by alcohols and general anesthetics. Pharmacol. Rev. 2014, 66, 396-412. [CrossRef] [PubMed]

42. Connolly, C.N.; Wafford, K.A. The cys-loop superfamily of ligand-gated ion channels: The impact of receptor structure on function. Biochem. Soc. Trans. 2004, 32, 529-534. [CrossRef] [PubMed]

43. Kozuska, J.L.; Paulsen, I.M. The cys-loop pentameric ligand-gated ion channel receptors: 50 years on. Can. J. Physiol. Pharmacol. 2012, 90, 771-782. [CrossRef] [PubMed]

44. Rosenbaum, D.M.; Rasmussen, S.G.F.; Kobilka, B.K. The structure and function of G-protein-coupled receptors. Nature 2009, 459, 356-363. [CrossRef] [PubMed]

45. Trkulja, V.; Salkovic, M.; Lackovic, Z. Signalling promiscuity of the metabotropic neurotransmitter receptors: Are there any functional consequences? Period. Biol. 1998, 100, 157-164.

46. Fryxell, K.J. The evolutionary divergence of neurotransmitter receptors and second-messenger pathways. J. Mol. Evol. 1995, 41, 85-97. [CrossRef] [PubMed] 
47. Katritch, V.; Cherezov, V.; Stevens, R.C. Structure-function of the G-protein-coupled receptor superfamily. Annu. Rev. Pharmacol. Toxicol. 2013, 53, 531-556. [CrossRef] [PubMed]

48. Pierce, K.L.; Premont, R.T.; Lefkowitz, R.J. Seven-transmembrane receptors. Nat. Rev. Mol. Cell Biol. 2002, 3, 639-650. [CrossRef] [PubMed]

49. Strader, C.D.; Fong, T.M.; Tota, M.R.; Underwood, D.; Dixon, R.A.F. Structure and function of G-protein-coupled receptors. Annu. Rev. Biochem. 1994, 63, 101-132. [CrossRef] [PubMed]

50. Willard, S.S.; Koochekpour, S. Glutamate, glutamate receptors, and downstream signaling pathways. Int. J. Biol. Sci. 2013, 9, 948-959. [CrossRef] [PubMed]

51. Karakas, E.; Regan, M.C.; Furukawa, H. Emerging structural insights into the function of ionotropic glutamate receptors. Trends Biochem. Sci. 2015, 40, 328-337. [CrossRef] [PubMed]

52. Harvey, B.H.; Shahid, M. Metabotropic and ionotropic glutamate receptors as neurobiological targets in anxiety and stress-related disorders: Focus on pharmacology and preclinical translational models. Pharmacol. Biochem. Behav. 2012, 100, 775-800. [CrossRef] [PubMed]

53. Hassel, B.; Dingledine, R. Chapter 17-Glutamate and glutamate receptors. In Basic Neurochemistry, 8th ed.; Brady, S.T., Siegel, G.J., Albers, R.W., Price, D.L., Eds.; Academic Press: New York, NY, USA, 2012; pp. 342-366.

54. Niswender, C.M.; Conn, P.J. Metabotropic glutamate receptors: Physiology, pharmacology, and disease. Annu. Rev. Pharmacol. Toxicol. 2010, 50, 295-322. [CrossRef] [PubMed]

55. Page, G.; Khidir, F.A.; Pain, S.; Barrier, L.; Fauconneau, B.; Guillard, O.; Piriou, A.; Hugon, J. Group I metabotropic glutamate receptors activate the p70S6 kinase via both mammalian target of rapamycin (mTOR) and extracellular signal-regulated kinase (ERK 1/2) signaling pathways in rat striatal and hippocampal synaptoneurosomes. Neurochem. Int. 2006, 49, 413-421. [CrossRef] [PubMed]

56. Saugstad, J.A.; Ingram, S.L. Group I metabotropic glutamate receptors (mGlu1 and mGlu5). In The Glutamate Receptors; Gereau, R.W., Swanson, G.T., Eds.; Humana Press: Totowa, NJ, USA, 2008; pp. 387-463.

57. Hermans, E.; Challiss, R.A. Structural, signalling and regulatory properties of the group I metabotropic glutamate receptors: Prototypic family C G-protein-coupled receptors. Biochem. J. 2001, 359, 465-484. [CrossRef] [PubMed]

58. Willard, S.S.; Koochekpour, S. Glutamate signaling in benign and malignant disorders: Current status, future perspectives, and therapeutic implications. Int. J. Biol. Sci. 2013, 9, 728-742. [CrossRef] [PubMed]

59. Iacovelli, L.; Bruno, V.; Salvatore, L.; Melchiorri, D.; Gradini, R.; Caricasole, A.; Barletta, E.; De Blasi, A.; Nicoletti, F. Native group-III metabotropic glutamate receptors are coupled to the mitogen-activated protein kinase/phosphatidylinositol-3-kinase pathways. J. Neurochem. 2002, 82, 216-223. [CrossRef] [PubMed]

60. Dhanasiri, A.K.S.; Fernandes, J.M.O.; Kiron, V. Glutamine synthetase activity and the expression of three glul paralogues in zebrafish during transport. Comp. Biochem. Physiol. Part B 2012, 163, 274-284. [CrossRef] [PubMed]

61. Lin, W.-H.; Wu, C.-H.; Chen, Y.-C.; Chow, W.-Y. Embryonic expression of zebrafish ampa receptor genes: Zygotic gria $2 \alpha$ expression initiates at the midblastula transition. Brain Res. 2006, 1110, 46-54. [CrossRef] [PubMed]

62. Hoppmann, V.; Wu, J.J.; Søviknes, A.M.; Helvik, J.V.; Becker, T.S. Expression of the eight AMPA receptor subunit genes in the developing central nervous system and sensory organs of zebrafish. Dev. Dyn. 2008, 237, 788-799. [CrossRef] [PubMed]

63. Cox, J.A.; Kucenas, S.; Voigt, M.M. Molecular characterization and embryonic expression of the family of N-methyl-D-aspartate receptor subunit genes in the zebrafish. Dev. Dyn. 2005, 234, 756-766. [CrossRef] [PubMed]

64. Haug, M.F.; Gesemann, M.; Mueller, T.; Neuhauss, S.C.F. Phylogeny and expression divergence of metabotropic glutamate receptor genes in the brain of zebrafish (Danio rerio). J. Comp. Neurol. 2013, 521, 1533-1560. [CrossRef] [PubMed]

65. Huang, Y.-Y.; Haug, M.F.; Gesemann, M.; Neuhauss, S.C.F. Novel expression patterns of metabotropic glutamate receptor 6 in the zebrafish nervous system. PLoS ONE 2012, 7, e35256. [CrossRef] [PubMed]

66. Rico, E.P.; de Oliveira, D.L.; Rosemberg, D.B.; Mussulini, B.H.; Bonan, C.D.; Dias, R.D.; Wofchuk, S.; Souza, D.O.; Bogo, M.R. Expression and functional analysis of $\mathrm{Na}^{+}$-dependent glutamate transporters from zebrafish brain. Brain Res. Bull. 2010, 81, 517-523. [CrossRef] [PubMed] 
67. Gesemann, M.; Lesslauer, A.; Maurer, C.M.; Schönthaler, H.B.; Neuhauss, S.C. Phylogenetic analysis of the vertebrate excitatory/neutral amino acid transporter (SLC1/EAAT) family reveals lineage specific subfamilies. BMC Evolut. Biol. 2010, 10, 1-15. [CrossRef] [PubMed]

68. Mueller, T.; Wullimann, M.F. Anatomy of neurogenesis in the early zebrafish brain. Dev. Brain Res. 2003, 140, 137-155. [CrossRef]

69. Schuurmans, C.; Guillemot, F. Molecular mechanisms underlying cell fate specification in the developing telencephalon. Curr. Opin. Neurobiol. 2002, 12, 26-34. [CrossRef]

70. Liguz-Lecznar, M.; Skangiel-Kramska, J. Vesicular glutamate transporters (VGLUTs): The three musketeers of glutamatergic system. Acta Neurobiol. Exp. 2007, 67, 207-218.

71. Bezzi, P.; Gundersen, V.; Galbete, J.L.; Seifert, G.; Steinhauser, C.; Pilati, E.; Volterra, A. Astrocytes contain a vesicular compartment that is competent for regulated exocytosis of glutamate. Nat. Neurosci. 2004, 7, 613-620. [CrossRef] [PubMed]

72. Gallo, V.; Ghiani, C.A. Glutamate receptors in glia: New cells, new inputs and new functions. Trends Pharmacol. Sci. 2000, 21, 252-258. [CrossRef]

73. Olsen, R.W.; Li, G.-D. Chapter 18-GABA. In Basic Neurochemistry, 8th ed.; Brady, S.T., Siegel, G.J., Albers, R.W., Price, D.L., Eds.; Academic Press: New York, NY, USA, 2012; pp. 367-376.

74. Pehrson, A.L.; Sanchez, C. Altered $\gamma$-aminobutyric acid neurotransmission in major depressive disorder: A critical review of the supporting evidence and the influence of serotonergic antidepressants. Drug Des. Devel. Ther. 2015, 9, 603-624. [CrossRef] [PubMed]

75. Kantrowitz, J.; Citrome, L.; Javitt, D. GABA B receptors, schizophrenia and sleep dysfunction. CNS Drugs 2009, 23, 681-691. [CrossRef] [PubMed]

76. Greenfield, L.J. Molecular mechanisms of antiseizure drug activity at GABA $\mathrm{A}_{\mathrm{A}}$ receptors. Seizure 2013, 22, 589-600. [CrossRef] [PubMed]

77. Ben-Ari, Y. Excitatory actions of GABA during development: The nature of the nurture. Nat. Rev. Neurosci. 2002, 3, 728-739. [CrossRef] [PubMed]

78. Reynolds, A.; Brustein, E.; Liao, M.; Mercado, A.; Babilonia, E.; Mount, D.B.; Drapeau, P. Neurogenic role of the depolarizing chloride gradient revealed by global overexpression of KCC2 from the onset of development. J. Neurosci. 2008, 28, 1588-1597. [CrossRef] [PubMed]

79. Rivera, C.; Voipio, J.; Payne, J.A.; Ruusuvuori, E.; Lahtinen, H.; Lamsa, K.; Pirvola, U.; Saarma, M.; Kaila, K. The $\mathrm{K}^{+} / \mathrm{Cl}^{-}$co-transporter KCC2 renders GABA hyperpolarizing during neuronal maturation. Nature 1999, 397, 251-255. [PubMed]

80. Yamada, J.; Okabe, A.; Toyoda, H.; Kilb, W.; Luhmann, H.J.; Fukuda, A. $\mathrm{Cl}^{-}$uptake promoting depolarizing GABA actions in immature rat neocortical neurones is mediated by NKCC1. J. Physiol. 2004, 557, 829-841. [CrossRef] [PubMed]

81. Bosma, P.T.; Blázquez, M.; Collins, M.A.; Bishop, J.D.; Drouin, G.; Priede, I.G.; Docherty, K.; Trudeau, V.L. Multiplicity of glutamic acid decarboxylases (GAD) in vertebrates: Molecular phylogeny and evidence for a new GAD paralog. Mol. Biol. Evol. 1999, 16, 397-404. [CrossRef] [PubMed]

82. Scimemi, A. Structure, function, and plasticity of GABA transporters. Front. Cell. Neurosci. 2014, 8, 161. [CrossRef] [PubMed]

83. Schousboe, A.; Bak, L.K.; Waagepetersen, H.S. Astrocytic control of biosynthesis and turnover of the neurotransmitters glutamate and GABA. Front. Endocrinol. 2013, 4, 102. [CrossRef] [PubMed]

84. Walls, A.B.; Waagepetersen, H.S.; Bak, L.K.; Schousboe, A.; Sonnewald, U. The glutamine-glutamate/GABA cycle: Function, regional differences in glutamate and GABA production and effects of interference with GABA metabolism. Neurochem. Res. 2015, 40, 402-409. [CrossRef] [PubMed]

85. Sigel, E.; Steinmann, M.E. Structure, function, and modulation of GABA $\mathrm{A}$ receptors. J. Biol. Chem. 2012, 287, 40224-40231. [CrossRef] [PubMed]

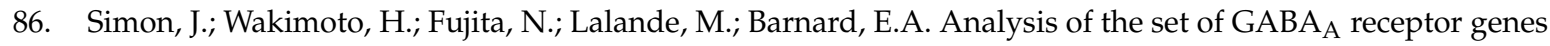
in the human genome. J. Biol. Chem. 2004, 279, 41422-41435. [CrossRef] [PubMed]

87. Bowery, N.G.; Bettler, B.; Froestl, W.; Gallagher, J.P.; Marshall, F.; Raiteri, M.; Bonner, T.I.; Enna, S.J.

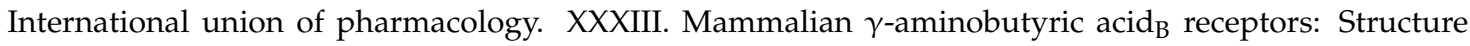
and function. Pharmacol. Rev. 2002, 54, 247-264. [CrossRef] [PubMed]

88. Pinard, A.; Seddik, R.; Bettler, B. GABA $\mathrm{B}$ receptors: Physiological functions and mechanisms of diversity. Adv. Pharmacol. (San Diego Calif.) 2010, 58, 231-255. 
89. Padgett, C.L.; Slesinger, P.A. GABA $\mathrm{B}$ receptor coupling to G-proteins and ion channels. In Advances in Pharmacology; Thomas, P.B., Ed.; Academic Press: San Diego, CA, USA, 2010; Volume 58, pp. 123-147.

90. Kullmann, D.M.; Ruiz, A.; Rusakov, D.M.; Scott, R.; Semyanov, A.; Walker, M.C. Presynaptic, extrasynaptic and axonal GABA A $_{\text {. }}$ receptors in the CNS: Where and why? Prog. Biophys. Mol. Biol. 2005, 87, $33-46$. [CrossRef] [PubMed]

91. Bettler, B.; Tiao, J.Y.-H. Molecular diversity, trafficking and subcellular localization of GABA $\mathrm{B}_{\mathrm{B}}$ receptors. Pharmacol. Ther. 2006, 110, 533-543. [CrossRef] [PubMed]

92. Martin, S.C.; Heinrich, G.; Sandell, J.H. Sequence and expression of glutamic acid decarboxylase isoforms in the developing zebrafish. J. Comp. Neurol. 1998, 396, 253-266. [CrossRef]

93. Mueller, T.; Vernier, P.; Wullimann, M.F. A phylotypic stage in vertebrate brain development: GABA cell patterns in zebrafish compared with mouse. J. Comp. Neurol. 2006, 494, 620-634. [CrossRef] [PubMed]

94. Mueller, T.; Wullimann, M.F. Chapter 3-Interpretation of data-How to use the atlas: Analysis. In Atlas of Early Zebrafish Brain Development, 2nd ed.; Elsevier: San Diego, CA, USA, 2016; pp. 159-204.

95. Higashijima, S.-I.; Schaefer, M.; Fetcho, J.R. Neurotransmitter properties of spinal interneurons in embryonic and larval zebrafish. J. Comp. Neurol. 2004, 480, 19-37. [CrossRef] [PubMed]

96. Kim, Y.J.; Nam, R.H.; Yoo, Y.M.; Lee, C.J. Identification and functional evidence of GABAergic neurons in parts of the brain of adult zebrafish (Danio rerio). Neurosci. Lett. 2004, 355, 29-32. [CrossRef] [PubMed]

97. Mueller, T.; Guo, S. The distribution of GAD67-mRNA in the adult zebrafish (teleost) forebrain reveals a prosomeric pattern and suggests previously unidentified homologies to tetrapods. J. Comp. Neurol. 2009, 516, 553-568. [CrossRef] [PubMed]

98. Delgado, L.; Schmachtenberg, O. Immunohistochemical localization of GABA, GAD65, and the receptor subunits $\mathrm{GABA}_{\mathrm{A} \alpha 1}$ and $\mathrm{GABA}_{\mathrm{B} 1}$ in the zebrafish cerebellum. Cerebellum 2008, 7, 444-450. [CrossRef] [PubMed]

99. Goldman-Rakic, P.S. The cortical dopamine system: Role in memory and cognition. Adv. Pharmacol. (San Diego Calif.) 1998, 42, 707-711.

100. Schultz, W. Updating dopamine reward signals. Curr. Opin. Neurobiol. 2013, 23, 229-238. [CrossRef] [PubMed]

101. Howes, O.D.; Kambeitz, J.; Kim, E.; Stahl, D.; Slifstein, M.; Abi-Dargham, A.; Kapur, S. The nature of dopamine dysfunction in schizophrenia and what this means for treatment: Meta-analysis of imaging studies. Arch. Gen. Psychiatry 2012, 69, 776-786. [CrossRef] [PubMed]

102. Daubner, S.C.; Le, T.; Wang, S. Tyrosine hydroxylase and regulation of dopamine synthesis. Arch. Biochem. Biophys. 2011, 508, 1-12. [CrossRef] [PubMed]

103. Cho, S.; Neff, N.H.; Hadjiconstantinou, M. Regulation of tyrosine hydroxylase and aromatic l-amino acid decarboxylase by dopaminergic drugs. Eur. J. Pharmacol. 1997, 323, 149-157. [CrossRef]

104. Gnegy, M.E. Chapter 14-Catecholamines. In Basic Neurochemistry, 8th ed.; Brady, S.T., Siegel, G.J., Albers, R.W., Price, D.L., Eds.; Academic Press: New York, NY, USA, 2012; pp. 283-299.

105. Benarroch, E.E. Monoamine transporters: Structure, regulation, and clinical implications. Neurology 2013, 81, 761-768. [CrossRef] [PubMed]

106. Lawal, H.O.; Krantz, D.E. Slc18: Vesicular neurotransmitter transporters for monoamines and acetylcholine. Mol. Asp. Med. 2013, 34, 360-372. [CrossRef] [PubMed]

107. Rudnick, G.; Kramer, R.; Blakely, R.D.; Murphy, D.L.; Verrey, F. The SLC6 transporters: Perspectives on structure, functions, regulation, and models for transporter dysfunction. Pflüg. Arch.—Eur. J. Physiol. 2014, 466, 25-42. [CrossRef] [PubMed]

108. Shih, J.C.; Chen, K.; Ridd, M.J. Role of MAO A and B in neurotransmitter metabolism and behavior. Pol. J. Pharmacol. 1999, 51, 25-29. [PubMed]

109. Callier, S.; Snapyan, M.; Le Crom, S.; Prou, D.; Vincent, J.D.; Vernier, P. Evolution and cell biology of dopamine receptors in vertebrates. Biol. Cell/Under Auspices Eur. Cell Biol. Organ. 2003, 95, 489-502. [CrossRef]

110. Missale, C.; Nash, S.R.; Robinson, S.W.; Jaber, M.; Caron, M.G. Dopamine receptors: From structure to function. Physiol. Rev. 1998, 78, 189-225. [PubMed]

111. Beaulieu, J.-M.; Espinoza, S.; Gainetdinov, R.R. Dopamine receptors-IUPHAR review 13. Br. J. Pharmacol. 2015, 172, 1-23. [CrossRef] [PubMed]

112. Candy, J.; Collet, C. Two tyrosine hydroxylase genes in teleosts. Biochim. Biophys. Acta 2005, 1727, 35-44. [CrossRef] [PubMed] 
113. Filippi, A.; Mahler, J.; Schweitzer, J.; Driever, W. Expression of the paralogous tyrosine hydroxylase encoding genes th 1 and th 2 reveals the full complement of dopaminergic and noradrenergic neurons in zebrafish larval and juvenile brain. J. Comp. Neurol. 2010, 518, 423-438. [CrossRef] [PubMed]

114. Yamamoto, K.; Ruuskanen, J.O.; Wullimann, M.F.; Vernier, P. Two tyrosine hydroxylase genes in vertebrates new dopaminergic territories revealed in the zebrafish brain. Mol. Cell. Neurosci. 2010, 43, $394-402$. [CrossRef] [PubMed]

115. Yamamoto, K.; Ruuskanen, J.O.; Wullimann, M.F.; Vernier, P. Differential expression of dopaminergic cell markers in the adult zebrafish forebrain. J. Comp. Neurol. 2011, 519, 576-598. [CrossRef] [PubMed]

116. Ren, G.; Li, S.; Zhong, H.; Lin, S. Zebrafish tyrosine hydroxylase 2 gene encodes tryptophan hydroxylase. J. Biol. Chem. 2013, 288, 22451-22459. [CrossRef] [PubMed]

117. Setini, A.; Pierucci, F.; Senatori, O.; Nicotra, A. Molecular characterization of monoamine oxidase in zebrafish (Danio rerio). Comp. Biochem. Physiol. Part B Biochem. Mol. Biol. 2005, 140, 153-161. [CrossRef] [PubMed]

118. Anichtchik, O.; Sallinen, V.; Peitsaro, N.; Panula, P. Distinct structure and activity of monoamine oxidase in the brain of zebrafish (Danio rerio). J. Comp. Neurol. 2006, 498, 593-610. [CrossRef] [PubMed]

119. Sallinen, V.; Sundvik, M.; Reenilä, I.; Peitsaro, N.; Khrustalyov, D.; Anichtchik, O.; Toleikyte, G.; Kaslin, J.; Panula, P. Hyperserotonergic phenotype after monoamine oxidase inhibition in larval zebrafish. J. Neurochem. 2009, 109, 403-415. [CrossRef] [PubMed]

120. Alazizi, A.; Liu, M.-Y.; Williams, F.E.; Kurogi, K.; Sakakibara, Y.; Suiko, M.; Liu, M.-C. Identification, characterization, and ontogenic study of a catechol o-methyltransferase from zebrafish. Aquat. Toxicol. 2011, 102, 18-23. [CrossRef] [PubMed]

121. Sprague, J.; Bayraktaroglu, L.; Clements, D.; Conlin, T.; Fashena, D.; Frazer, K.; Haendel, M.; Howe, D.G.; Mani, P.; Ramachandran, S.; et al. The zebrafish information network: The zebrafish model organism database. Nucleic Acids Res. 2006, 34, D581-D585. [CrossRef] [PubMed]

122. Ruuskanen, J.O.; Laurila, J.; Xhaard, H.; Rantanen, V.V.; Vuoriluoto, K.; Wurster, S.; Marjamaki, A.; Vainio, M.; Johnson, M.S.; Scheinin, M. Conserved structural, pharmacological and functional properties among the three human and five zebrafish alpha 2-adrenoceptors. Br. J. Pharmacol. 2005, 144, 165-177. [CrossRef] [PubMed]

123. Schweitzer, J.; Löhr, H.; Filippi, A.; Driever, W. Dopaminergic and noradrenergic circuit development in zebrafish. Dev. Neurobiol. 2012, 72, 256-268. [CrossRef] [PubMed]

124. Rink, E.; Wullimann, M.F. Development of the catecholaminergic system in the early zebrafish brain: An immunohistochemical study. Dev. Brain Res. 2002, 137, 89-100. [CrossRef]

125. Rink, E.; Wullimann, M.F. The teleostean (zebrafish) dopaminergic system ascending to the subpallium (striatum) is located in the basal diencephalon (posterior tuberculum). Brain Res. 2001, 889, 316-330. [CrossRef]

126. Becker, T.; Wullimann, M.F.; Becker, C.G.; Bernhardt, R.R.; Schachner, M. Axonal regrowth after spinal cord transection in adult zebrafish. J. Comp. Neurol. 1997, 377, 577-595. [CrossRef]

127. Parker, M.O.; Brock, A.J.; Walton, R.T.; Brennan, C.H. The role of zebrafish (Danio rerio) in dissecting the genetics and neural circuits of executive function. Front. Neural Circuits 2013, 7, 1-13. [CrossRef] [PubMed]

128. Panula, P.; Sundvik, M.; Karlstedt, K. Developmental roles of brain histamine. Trends Neurosci. 2014, 37, 159-168. [CrossRef] [PubMed]

129. Barreiro-Iglesias, A.; Mysiak, K.S.; Adrio, F.; Rodicio, M.C.; Becker, C.G.; Becker, T.; Anadon, R. Distribution of glycinergic neurons in the brain of glycine transporter-2 transgenic $\operatorname{Tg}(g l y t 2: G f p)$ adult zebrafish: Relationship to brain-spinal descending systems. J. Comp. Neurol. 2013, 521, 389-425. [CrossRef] [PubMed]

130. Haas, H.L.; Sergeeva, O.A.; Selbach, O. Histamine in the nervous system. Physiol. Rev. 2008, 88, $1183-1241$. [CrossRef] [PubMed]

131. Tomkins, D.M.; Sellers, E.M. Addiction and the brain: The role of neurotransmitters in the cause and treatment of drug dependence. Can. Med. Assoc. J. 2001, 164, 817-821.

132. Dalley, J.W.; Roiser, J.P. Dopamine, serotonin and impulsivity. Neuroscience 2012, 215, 42-58. [CrossRef] [PubMed]

133. Perry, E.; Walker, M.; Grace, J.; Perry, R. Acetylcholine in mind: A neurotransmitter correlate of consciousness? Trends Neurosci. 1999, 22, 273-280. [CrossRef]

134. Filippi, A.; Mueller, T.; Driever, W. Vglut2 and gad expression reveal distinct patterns of dual GABAergic versus glutamatergic cotransmitter phenotypes of dopaminergic and noradrenergic neurons in the zebrafish brain. J. Comp. Neurol. 2014, 522, 2019-2037. [CrossRef] [PubMed] 
135. Ma, P.M. Catecholaminergic systems in the zebrafish. III. Organization and projection pattern of medullary dopaminergic and noradrenergic neurons. J. Comp. Neurol. 1997, 381, 411-427. [CrossRef]

136. McLean, D.L.; Fetcho, J.R. Ontogeny and innervation patterns of dopaminergic, noradrenergic, and serotonergic neurons in larval zebrafish. J. Comp. Neurol. 2004, 480, 38-56. [CrossRef] [PubMed]

137. Kaslin, J.; Panula, P. Comparative anatomy of the histaminergic and other aminergic systems in zebrafish (Danio rerio). J. Comp. Neurol. 2001, 440, 342-377. [CrossRef] [PubMed]

138. Ma, P.M. Catecholaminergic systems in the zebrafish. II. Projection pathways and pattern of termination of the locus coeruleus. J. Comp. Neurol. 1994, 344, 256-269. [CrossRef] [PubMed]

139. Daubert, E.A.; Condron, B.G. Serotonin: A regulator of neuronal morphology and circuitry. Trends Neurosci. 2010, 33, 424-434. [CrossRef] [PubMed]

140. Gaspar, P.; Cases, O.; Maroteaux, L. The developmental role of serotonin: News from mouse molecular genetics. Nat. Rev. Neurosci. 2003, 4, 1002-1012. [CrossRef] [PubMed]

141. Lucki, I. The spectrum of behaviors influenced by serotonin. Biol. Psychiatry 1998, 44, 151-162. [CrossRef]

142. Parsey, R.V. Serotonin receptor imaging: Clinically useful? J. Nucl. Med. 2010, 51, 1495-1498. [CrossRef] [PubMed]

143. Walther, D.J.; Bader, M. A unique central tryptophan hydroxylase isoform. Biochem. Pharmacol. 2003, 66, 1673-1680. [CrossRef]

144. Mohammad-Zadeh, L.F.; Moses, L.; Gwaltney-Brant, S.M. Serotonin: A review. J. Vet. Pharmacol. Ther. 2008, 31, 187-199. [CrossRef] [PubMed]

145. Hensler, J.G. Chapter 15-Serotonin. In Basic Neurochemistry, 8th ed.; Brady, S.T., Siegel, G.J., Albers, R.W., Price, D.L., Eds.; Academic Press: New York, NY, USA, 2012; pp. 300-322.

146. Nichols, D.E.; Nichols, C.D. Serotonin receptors. Chem. Rev. 2008, 108, 1614-1641. [CrossRef] [PubMed]

147. Bellipanni, G.; Rink, E.; Bally-Cuif, L. Cloning of two tryptophan hydroxylase genes expressed in the diencephalon of the developing zebrafish brain. Mech. Dev. 2002, 119 (Suppl.), S215-S220. [CrossRef]

148. Teraoka, H.; Russell, C.; Regan, J.; Chandrasekhar, A.; Concha, M.L.; Yokoyama, R.; Higashi, K.; Take-uchi, M.; Dong, W.; Hiraga, T.; et al. Hedgehog and fgf signaling pathways regulate the development of tphR-expressing serotonergic raphe neurons in zebrafish embryos. J. Neurobiol. 2004, 60, 275-288. [CrossRef] [PubMed]

149. Lillesaar, C. The serotonergic system in fish. J. Chem. Neuroanat. 2011, 41, 294-308. [CrossRef] [PubMed]

150. Herculano, A.M.; Maximino, C. Serotonergic modulation of zebrafish behavior: Towards a paradox. Prog. Neuro-Psychopharmacol. Biol. Psychiatry 2014, 55, 50-66. [CrossRef] [PubMed]

151. Lillesaar, C.; Tannhauser, B.; Stigloher, C.; Kremmer, E.; Bally-Cuif, L. The serotonergic phenotype is acquired by converging genetic mechanisms within the zebrafish central nervous system. Dev. Dyn. 2007, 236, 1072-1084. [CrossRef] [PubMed]

152. Norton, W.H.J.; Folchert, A.; Bally-Cuif, L. Comparative analysis of serotonin receptor (HTR1A/HTR1B families) and transporter (slc6a4a/b) gene expression in the zebrafish brain. J. Comp. Neurol. 2008, 511, 521-542. [CrossRef] [PubMed]

153. Picciotto, M.R.; Higley, M.J.; Mineur, Y.S. Acetylcholine as a neuromodulator: Cholinergic signaling shapes nervous system function and behavior. Neuron 2012, 76, 116-129. [CrossRef] [PubMed]

154. Alkondon, M.; Rocha, E.S.; Maelicke, A.; Albuquerque, E.X. Diversity of nicotinic acetylcholine receptors in rat brain. V. Alpha-bungarotoxin-sensitive nicotinic receptors in olfactory bulb neurons and presynaptic modulation of glutamate release. J. Pharmacol. Exp. Ther. 1996, 278, 1460-1471. [PubMed]

155. Kenney, J.W.; Florian, C.; Portugal, G.S.; Abel, T.; Gould, T.J. Involvement of hippocampal jun-n terminal kinase pathway in the enhancement of learning and memory by nicotine. Neuropsychopharmacology 2010, 35, 483-492. [CrossRef] [PubMed]

156. Fisher, S.K.; Wonnacott, S. Chapter 13-Acetylcholine. In Basic Neurochemistry, 8th ed.; Brady, S.T., Siegel, G.J., Albers, R.W., Price, D.L., Eds.; Academic Press: New York, NY, USA, 2012; pp. 258-282.

157. Yakel, J.L. Cholinergic receptors: Functional role of nicotinic ach receptors in brain circuits and disease. Pflüg. Arch. Eur. J. Physiol. 2013, 465, 441-450. [CrossRef] [PubMed]

158. Brown, D.A. Muscarinic acetylcholine receptors (mAChRs) in the nervous system: Some functions and mechanisms. J. Mol. Neurosci. 2010, 41, 340-346. [CrossRef] [PubMed]

159. Zirger, J.M.; Beattie, C.E.; McKay, D.B.; Thomas Boyd, R. Cloning and expression of zebrafish neuronal nicotinic acetylcholine receptors. Gene Expr. Patterns 2003, 3, 747-754. [CrossRef] 
160. Papke, R.L.; Ono, F.; Stokes, C.; Urban, J.M.; Boyd, R.T. The nicotinic acetylcholine receptors of zebrafish and an evaluation of pharmacological tools used for their study. Biochem. Pharmacol. 2012, 84, 352-365. [CrossRef] [PubMed]

161. Williams, F.E.; Messer, W.S., Jr. Muscarinic acetylcholine receptors in the brain of the zebrafish (Danio rerio) measured by radioligand binding techniques. Comp. Biochem. Physiol. Part C: Toxicol. Pharmacol. 2004, 137, 349-353. [CrossRef] [PubMed]

162. Kaslin, J.; Nystedt, J.M.; Ostergard, M.; Peitsaro, N.; Panula, P. The orexin/hypocretin system in zebrafish is connected to the aminergic and cholinergic systems. J. Neurosci. 2004, 24, 2678-2689. [CrossRef] [PubMed]

163. Clemente, D.; Porteros, A.; Weruaga, E.; Alonso, J.R.; Arenzana, F.J.; Aijon, J.; Arevalo, R. Cholinergic elements in the zebrafish central nervous system: Histochemical and immunohistochemical analysis. J. Comp. Neurol. 2004, 474, 75-107. [CrossRef] [PubMed]

164. Mueller, T.; Vernier, P.; Wullimann, M.F. The adult central nervous cholinergic system of a neurogenetic model animal, the zebrafish Danio rerio. Brain Res. 2004, 1011, 156-169. [CrossRef] [PubMed]

165. Arenzana, F.J.; Clemente, D.; Sánchez-González, R.; Porteros, Á.; Aijón, J.; Arévalo, R. Development of the cholinergic system in the brain and retina of the zebrafish. Brain Res. Bull. 2005, 66, 421-425. [CrossRef] [PubMed]

166. Haas, H.; Panula, P. The role of histamine and the tuberomamillary nucleus in the nervous system. Nat. Rev. Neurosci. 2003, 4, 121-130. [CrossRef] [PubMed]

167. Sundvik, M.; Kudo, H.; Toivonen, P.; Rozov, S.; Chen, Y.C.; Panula, P. The histaminergic system regulates wakefulness and orexin/hypocretin neuron development via histamine receptor $\mathrm{H} 1$ in zebrafish. FASEB J. 2011, 25, 4338-4347. [CrossRef] [PubMed]

168. Schwartz, J.C.; Arrang, J.M.; Garbarg, M.; Pollard, H.; Ruat, M. Histaminergic transmission in the mammalian brain. Physiol. Rev. 1991, 71, 1-51. [PubMed]

169. Leurs, R.; Hough, L.B.; Blandina, P.; Haas, H.L. Chapter 16-Histamine. In Basic Neurochemistry, 8th ed.; Brady, S.T., Siegel, G.J., Albers, R.W., Price, D.L., Eds.; Academic Press: New York, NY, USA, 2012; pp. 323-341.

170. Eriksson, K.S.; Peitsaro, N.; Karlstedt, K.; Kaslin, J.; Panula, P. Development of the histaminergic neurons and expression of histidine decarboxylase mRNA in the zebrafish brain in the absence of all peripheral histaminergic systems. Eur. J. Neurosci. 1998, 10, 3799-3812. [CrossRef] [PubMed]

171. Onodera, K.; Yamatodani, A.; Watanabe, T.; Wadas, H. Neuropharmacology of the histaminergic neuron system in the brain and its relationship with behavioral disorders. Prog. Neurobiol. 1994, 42, 685-702. [CrossRef]

172. Kukko-Lukjanov, T.K.; Panula, P. Subcellular distribution of histamine, GABA and galanin in tuberomamillary neurons in vitro. J. Chem. Neuroanat. 2003, 25, 279-292. [CrossRef]

173. Connelly, W.M.; Shenton, F.C.; Lethbridge, N.; Leurs, R.; Waldvogel, H.J.; Faull, R.L.; Lees, G.; Chazot, P.L. The histamine h4 receptor is functionally expressed on neurons in the mammalian CNS. Br. J. Pharmacol. 2009, 157, 55-63. [CrossRef] [PubMed]

174. Drutel, G.; Peitsaro, N.; Karlstedt, K.; Wieland, K.; Smit, M.J.; Timmerman, H.; Panula, P.; Leurs, R. Identification of rat $\mathrm{H} 3$ receptor isoforms with different brain expression and signaling properties. Mol. Pharmacol. 2001, 59, 1-8. [PubMed]

175. Giovannini, M.G.; Efoudebe, M.; Passani, M.B.; Baldi, E.; Bucherelli, C.; Giachi, F.; Corradetti, R.; Blandina, P. Improvement in fear memory by histamine-elicited ERK2 activation in hippocampal CA3 cells. J. Neurosci. 2003, 23, 9016-9023. [PubMed]

176. Mariottini, C.; Scartabelli, T.; Bongers, G.; Arrigucci, S.; Nosi, D.; Leurs, R.; Chiarugi, A.; Blandina, P.; Pellegrini-Giampietro, D.E.; Passani, M.B. Activation of the histaminergic H3 receptor induces phosphorylation of the Akt/GSK-3 $\beta$ pathway in cultured cortical neurons and protects against neurotoxic insults. J. Neurochem. 2009, 110, 1469-1478. [CrossRef] [PubMed]

177. Peitsaro, N.; Sundvik, M.; Anichtchik, O.V.; Kaslin, J.; Panula, P. Identification of zebrafish histamine H1, H2 and H3 receptors and effects of histaminergic ligands on behavior. Biochem. Pharmacol. 2007, 73, 1205-1214. [CrossRef] [PubMed]

178. Sundvik, M.; Panula, P. Organization of the histaminergic system in adult zebrafish (Danio rerio) brain: Neuron number, location, and cotransmitters. J. Comp. Neurol. 2012, 520, 3827-3845. [CrossRef] [PubMed] 
179. McDearmid, J.R.; Liao, M.; Drapeau, P. Glycine receptors regulate interneuron differentiation during spinal network development. Proc. Natl. Acad. Sci. USA 2006, 103, 9679-9684. [CrossRef] [PubMed]

180. Hernandes, M.S.; Troncone, L.R. Glycine as a neurotransmitter in the forebrain: A short review. J. Neural Trans. (Vienna Austria: 1996) 2009, 116, 1551-1560. [CrossRef] [PubMed]

181. Raiteri, L.; Stigliani, S.; Usai, C.; Diaspro, A.; Paluzzi, S.; Milanese, M.; Raiteri, M.; Bonanno, G. Functional expression of release-regulating glycine transporters GLYT1 on GABAergic neurons and GLY2 on astrocytes in mouse spinal cord. Neurochem. Int. 2008, 52, 103-112. [CrossRef] [PubMed]

182. Bowery, N.G.; Smart, T.G. GABA and glycine as neurotransmitters: A brief history. Br. J. Pharmacol. 2006, 147, S109-S119. [CrossRef] [PubMed]

183. Cummings, K.A.; Popescu, G.K. Glycine-dependent activation of nmda receptors. J. Gen. Physiol. 2015, 145, 513-527. [CrossRef] [PubMed]

184. Yevenes, G.E.; Peoples, R.W.; Tapia, J.C.; Parodi, J.; Soto, X.; Olate, J.; Aguayo, L.G. Modulation of glycine-activated ion channel function by G-protein $\beta \gamma$ subunits. Nat. Neurosci. 2003, 6, 819-824. [CrossRef] [PubMed]

185. Fucile, S.; de Saint Jan, D.; David-Watine, B.; Korn, H.; Bregestovski, P. Comparison of glycine and GABA actions on the zebrafish homomeric glycine receptor. J. Physiol. 1999, 517 Pt 2, 369-383. [CrossRef] [PubMed]

186. Imboden, M.; Devignot, V.; Goblet, C. Phylogenetic relationships and chromosomal location of five distinct glycine receptor subunit genes in the teleost Danio rerio. Dev. Genes Evol. 2001, 211, 415-422. [PubMed]

187. Higashijima, S.; Mandel, G.; Fetcho, J.R. Distribution of prospective glutamatergic, glycinergic, and GABAergic neurons in embryonic and larval zebrafish. J. Comp. Neurol. 2004, 480, 1-18. [CrossRef] [PubMed]

188. Moly, P.K.; Ikenaga, T.; Kamihagi, C.; Islam, A.F.M.T.; Hatta, K. Identification of initially appearing glycine-immunoreactive neurons in the embryonic zebrafish brain. Dev. Neurobiol. 2014, 74, 616-632. [CrossRef] [PubMed]

189. Joca, S.R.; Moreira, F.A.; Wegener, G. Atypical neurotransmitters and the neurobiology of depression. CNS Neurol. Disord.-Drug Targets 2015, 14, 1001-1011. [CrossRef] [PubMed]

190. Holmqvist, B.; Ebbesson, L.; Alm, P. Nitric oxide and the zebrafish (Danio rerio): Developmental neurobiology and brain neurogenesis. In Advances in Experimental Biology; Bruno, T., Barry, T., Eds.; Elsevier: Amsterdam, The Netherlands, 2007; Volume 1, pp. 229-465.

191. Chatterjee, D.; Gerlai, R. High precision liquid chromatography analysis of dopaminergic and serotoninergic responses to acute alcohol exposure in zebrafish. Behav. Brain Res. 2009, 200, 208-213. [CrossRef] [PubMed]

192. Milanese, C.; Sager, J.J.; Bai, Q.; Farrell, T.C.; Cannon, J.R.; Greenamyre, J.T.; Burton, E.A. Hypokinesia and reduced dopamine levels in zebrafish lacking $\beta$ - and $\gamma 1$-synucleins. J. Biol. Chem. 2012, 287, 2971-2983. [CrossRef] [PubMed]

193. Wirbisky, S.E.; Weber, G.J.; Lee, J.W.; Cannon, J.R.; Freeman, J.L. Novel dose-dependent alterations in excitatory GABA during embryonic development associated with lead $(\mathrm{Pb})$ neurotoxicity. Toxicol. Lett. 2014, 229, 1-8. [CrossRef] [PubMed]

194. Pan, Y.; Chatterjee, D.; Gerlai, R. Strain dependent gene expression and neurochemical levels in the brain of zebrafish: Focus on a few alcohol related targets. Physiol. Behav. 2012, 107, 773-780. [CrossRef] [PubMed]

195. Tufi, S.; Leonards, P.; Lamoree, M.; de Boer, J.; Legler, J.; Legradi, J. Changes in neurotransmitter profiles during early zebrafish (Danio rerio) development and after pesticide exposure. Environ. Sci. Technol. 2016, 50, 3222-3230. [CrossRef] [PubMed]

196. Jones, L.J.; McCutcheon, J.E.; Young, A.M.J.; Norton, W.H.J. Neurochemical measurements in the zebrafish brain. Front. Behav. Neurosci. 2015, 9, 246. [CrossRef] [PubMed]

197. Lopez Patino, M.A.; Yu, L.; Yamamoto, B.K.; Zhdanova, I.V. Gender differences in zebrafish responses to cocaine withdrawal. Physiol. Behav. 2008, 95, 36-47. [CrossRef] [PubMed]

198. Cambier, S.; Gonzalez, P.; Mesmer-Dudons, N.; Brèthes, D.; Fujimura, M.; Bourdineaud, J.-P. Effects of dietary methylmercury on the zebrafish brain: Histological, mitochondrial, and gene transcription analyses. BioMetals 2012, 25, 165-180. [CrossRef] [PubMed]

199. Wirbisky, S.E.; Weber, G.J.; Sepulveda, M.S.; Xiao, C.; Cannon, J.R.; Freeman, J.L. Developmental origins of neurotransmitter and transcriptome alterations in adult female zebrafish exposed to atrazine during embryogenesis. Toxicology 2015, 333, 156-167. [CrossRef] [PubMed] 
200. Freeman, J.L.; Weber, G.J.; Peterson, S.M.; Nie, L.H. Embryonic ionizing radiation exposure results in expression alterations of genes associated with cardiovascular and neurological development, function, and disease and modified cardiovascular function in zebrafish. Front. Genet. 2014, 5, 268. [CrossRef] [PubMed]

201. Peterson, S.M.; Zhang, J.; Weber, G.; Freeman, J.L. Global gene expression analysis reveals dynamic and developmental stage-dependent enrichment of lead-induced neurological gene alterations. Environ. Health Perspect. 2011, 119, 615-621. [CrossRef] [PubMed]

202. Weber, G.J.; Sepulveda, M.S.; Peterson, S.M.; Lewis, S.S.; Freeman, J.L. Transcriptome alterations following developmental atrazine exposure in zebrafish are associated with disruption of neuroendocrine and reproductive system function, cell cycle, and carcinogenesis. Toxicol. Sci. 2013, 132, 458-466. [CrossRef] [PubMed]

203. Scholz, S. Zebrafish embryos as an alternative model for screening of drug-induced organ toxicity. Arch. Toxicol. 2013, 87, 767-769. [CrossRef] [PubMed]

204. Wang, Z.; Gerstein, M.; Snyder, M. RNA-seq: A revolutionary tool for transcriptomics. Nat. Rev. Genet. 2009, 10, 57-63. [CrossRef] [PubMed]

205. Aanes, H.; Winata, C.L.; Lin, C.H.; Chen, J.P.; Srinivasan, K.G.; Lee, S.G.P.; Lim, A.Y.M.; Hajan, H.S.; Collas, P.; Bourque, G.; et al. Zebrafish mRNA sequencing deciphers novelties in transcriptome dynamics during maternal to zygotic transition. Genome Res. 2011, 21, 1328-1338. [CrossRef] [PubMed]

206. Ahmad, F.; Richardson, M.K.; Noldus, L.P.J.J.; Tegelenbosch, R.A.J. Zebrafish embryos and larvae in behavioural assays. Behaviour 2012, 149, 1241-1281. [CrossRef]

207. Bailey, J.; Oliveri, A.; Levin, E.D. Zebrafish model systems for developmental neurobehavioral toxicology. Birth Defects Res. Part C Embryo Today 2013, 99, 14-23. [CrossRef] [PubMed]

208. Blaser, R.E.; Chadwick, L.; McGinnis, G.C. Behavioral measures of anxiety in zebrafish (Danio rerio). Behav. Brain Res. 2010, 208, 56-62. [CrossRef] [PubMed]

209. Budick, S.A.; O'Malley, D.M. Locomotor repertoire of the larval zebrafish: Swimming, turning and prey capture. J. Exp. Biol. 2000, 203, 2565-2579. [PubMed]

210. Buske, C.; Gerlai, R. Diving deeper into zebrafish development of social behavior: Analyzing high resolution data. J. Neurosci. Methods 2014, 234, 66-72. [CrossRef] [PubMed]

211. Champagne, D.L.; Hoefnagels, C.C.M.; de Kloet, R.E.; Richardson, M.K. Translating rodent behavioral repertoire to zebrafish (Danio rerio): Relevance for stress research. Behav. Brain Res. 2010, 214, 332-342. [CrossRef] [PubMed]

212. Egan, R.J.; Bergner, C.L.; Hart, P.C.; Cachat, J.M.; Canavello, P.R.; Elegante, M.F.; Elkhayat, S.I.; Bartels, B.K.; Tien, A.K.; Tien, D.H.; et al. Understanding behavioral and physiological phenotypes of stress and anxiety in zebrafish. Behav. Brain Res. 2009, 205, 38-44. [CrossRef] [PubMed]

213. Gerlai, R. Fish in behavior research: Unique tools with a great promise! J. Neurosci. Methods 2014, 234, 54-58. [CrossRef] [PubMed]

214. Kalueff, A.V.; Gebhardt, M.; Stewart, A.M.; Cachat, J.M.; Brimmer, M.; Chawla, J.S.; Craddock, C.; Kyzar, E.J.; Roth, A.; Landsman, S.; et al. Towards a comprehensive catalog of zebrafish behavior 1.0 and beyond. Zebrafish 2013, 10, 70-86. [CrossRef] [PubMed]

215. Kalueff, A.V.; Stewart, A.M.; Gerlai, R. Zebrafish as an emerging model for studying complex brain disorders. Trends Pharmacol. Sci. 2014, 35, 63-75. [CrossRef] [PubMed]

216. Maximino, C.; de Brito, T.M.; da Silva Batista, A.W.; Herculano, A.M.; Morato, S.; Gouveia, A., Jr. Measuring anxiety in zebrafish: A critical review. Behav. Brain Res. 2010, 214, 157-171. [CrossRef] [PubMed]

217. Nguyen, M.; Stewart, A.M.; Kalueff, A.V. Aquatic blues: Modeling depression and antidepressant action in zebrafish. Prog. Neuro-Psychopharmacol. Biol. Psychiatry 2014, 55, 26-39. [CrossRef] [PubMed]

218. Steenbergen, P.J.; Richardson, M.K.; Champagne, D.L. The use of the zebrafish model in stress research. Prog. Neuro-Psychopharmacol. Biol. Psychiatry 2011, 35, 1432-1451. [CrossRef] [PubMed]

219. Kalueff, A.V.; Echevarria, D.J.; Homechaudhuri, S.; Stewart, A.M.; Collier, A.D.; Kaluyeva, A.A.; Li, S.; Liu, Y.; Chen, P.; Wang, J.; et al. Zebrafish neurobehavioral phenomics for aquatic neuropharmacology and toxicology research. Aquat. Toxicol. 2016, 170, 297-309. [CrossRef] [PubMed]

220. Parker, M.O. Adult vertebrate behavioural aquatic toxicology: Reliability and validity. Aquat. Toxicol. 2016, 170, 323-329. [CrossRef] [PubMed]

221. Connaughton, V.P.; Behar, T.N.; Liu, W.L.S.; Massey, S.C. Immunocytochemical localization of excitatory and inhibitory neurotransmitters in the zebrafish retina. Vis. Neurosci. 1999, 16, 483-490. [CrossRef] [PubMed] 
222. DeCarvalho, T.N.; Subedi, A.; Rock, J.; Harfe, B.D.; Thisse, C.; Thisse, B.; Halpern, M.E.; Hong, E. Neurotransmitter map of the asymmetric dorsal habenular nuclei of zebrafish. Genesis 2014, 52, 636-655. [CrossRef] [PubMed]

223. Fetcho, J.R.; O'Malley, D.M. Imaging neuronal networks in behaving animals. Curr. Opin. Neurobiol. 1997, 7, 832-838. [CrossRef]

224. Marvin, J.S.; Borghuis, B.G.; Tian, L.; Cichon, J.; Harnett, M.T.; Akerboom, J.; Gordus, A.; Renninger, S.L.; Chen, T.W.; Bargmann, C.I.; et al. An optimized fluorescent probe for visualizing glutamate neurotransmission. Nat. Methods 2013, 10, 162-170. [CrossRef] [PubMed]

225. Ahrens, M.B.; Orger, M.B.; Robson, D.N.; Li, J.M.; Keller, P.J. Whole-brain functional imaging at cellular resolution using light-sheet microscopy. Nat. Methods 2013, 10, 413-420. [CrossRef] [PubMed]

226. Garaschuk, O.; Milos, R.-I.; Konnerth, A. Targeted bulk-loading of fluorescent indicators for two-photon brain imaging in vivo. Nat. Protoc. 2006, 1, 380-386. [CrossRef] [PubMed]

227. O'Malley, D.M.; Zhou, Q.; Gahtan, E. Probing neural circuits in the zebrafish: A suite of optical techniques. Methods 2003, 30, 49-63. [CrossRef]

228. Arrenberg, A.B.; Driever, W. Integrating anatomy and function for zebrafish circuit analysis. Front. Neural Circuits 2013, 7. [CrossRef] [PubMed]

229. Bruni, G.; Lakhani, P.; Kokel, D. Discovering novel neuroactive drugs through high-throughput behavior-based chemical screening in the zebrafish. Front. Pharmacol. 2014, 5. [CrossRef] [PubMed]

230. Magno, L.D.P.; Fontes, A.; Goncalves, B.M.N.; Gouveia, A. Pharmacological study of the light/dark preference test in zebrafish (Danio rerio): Waterborne administration. Pharmacol. Biochem. Behav. 2015, 135, 169-176. [CrossRef] [PubMed]

231. Maximino, C.; da Silva, A.W.B.; Gouveia, A., Jr.; Herculano, A.M. Pharmacological analysis of zebrafish (Danio rerio) scototaxis. Prog. Neuro-Psychopharmacol. Biol. Psychiatry 2011, 35, 624-631. [CrossRef] [PubMed]

232. McCarroll, M.N.; Gendelev, L.; Keiser, M.J.; Kokel, D. Leveraging large-scale behavioral profiling in zebrafish to explore neuroactive polypharmacology. ACS Chem. Biol. 2016, 11, 842-849. [CrossRef] [PubMed]

233. Rihel, J.; Schier, A.F. Behavioral screening for neuroactive drugs in zebrafish. Dev. Neurobiol. 2012, 72, 373-385. [CrossRef] [PubMed]

234. Stewart, A.M.; Grieco, F.; Tegelenbosch, R.A.J.; Kyzar, E.J.; Nguyen, M.; Kaluyeva, A.; Song, C.; Noldus, L.; Kalueff, A.V. A novel 3D method of locomotor analysis in adult zebrafish: Implications for automated detection of CNS drug-evoked phenotypes. J. Neurosci. Methods 2015, 255, 66-74. [CrossRef] [PubMed]

235. Maximino, C.; Herculano, A.M. A review of monoaminergic neuropsychopharmacology in zebrafish. Zebrafish 2010, 7, 359-378. [CrossRef] [PubMed]

236. Rico, E.P.; Rosemberg, D.B.; Dias, R.D.; Bogo, M.R.; Bonan, C.D. Ethanol alters acetylcholinesterase activity and gene expression in zebrafish brain. Toxicol. Lett. 2007, 174, 25-30. [CrossRef] [PubMed]

237. Chatterjee, D.; Shams, S.; Gerlai, R. Chronic and acute alcohol administration induced neurochemical changes in the brain: Comparison of distinct zebrafish populations. Amino Acids 2014, 46, 921-930. [CrossRef] [PubMed]

238. Puttonen, H.; Sundvik, M.; Rozov, S.; Chen, Y.-C.; Panula, P. Acute ethanol treatment upregulates th1, th2 and $h d c$ in larval zebrafish in stable networks. Front. Neural Circuits 2013, 7. [CrossRef] [PubMed]

239. Gerlai, R.; Ahmad, F.; Prajapati, S. Differences in acute alcohol-induced behavioral responses among zebrafish populations. Alcohol. Clin. Exp. Res. 2008, 32, 1763-1773. [CrossRef] [PubMed]

240. Gerlai, R.; Lee, V.; Blaser, R. Effects of acute and chronic ethanol exposure on the behavior of adult zebrafish (Danio rerio). Pharmacol. Biochem. Behav. 2006, 85, 752-761. [CrossRef] [PubMed]

241. Tran, S.; Gerlai, R. Time-course of behavioural changes induced by ethanol in zebrafish (Danio rerio). Behav. Brain Res. 2013, 252, 204-213. [CrossRef] [PubMed]

242. Kurta, A.; Palestis, B.G. Effects of ethanol on the shoaling behavior of zebrafish (Danio rerio). Dose-Response 2010, 8, 527-533. [CrossRef] [PubMed]

243. Pannia, E.; Tran, S.; Rampersad, M.; Gerlai, R. Acute ethanol exposure induces behavioural differences in two zebrafish (Danio rerio) strains: A time course analysis. Behav. Brain Res. 2014, 259, 174-185. [CrossRef] [PubMed]

244. Bailey, J.M.; Oliveri, A.N.; Zhang, C.; Frazier, J.M.; Mackinnon, S.; Cole, G.J.; Levin, E.D. Long-term behavioral impairment following acute embryonic ethanol exposure in zebrafish. Neurotoxicol. Teratol. 2015, 48, 1-8. [CrossRef] [PubMed] 
245. Luchiari, A.C.; Salajan, D.C.; Gerlai, R. Acute and chronic alcohol administration: Effects on performance of zebrafish in a latent learning task. Behav. Brain Res. 2015, 282, 76-83. [CrossRef] [PubMed]

246. Echevarria, D.J.; Toms, C.N.; Jouandot, D.J. Alcohol-induced behavior change in zebrafish models. Rev. Neurosci. 2011, 22, 85-93. [CrossRef] [PubMed]

247. Zenki, K.C.; Mussulini, B.H.M.; Rico, E.P.; Oliveira, D.L.d.; Rosemberg, D.B. Effects of ethanol and acetaldehyde in zebrafish brain structures: An in vitro approach on glutamate uptake and on toxicity-related parameters. Toxicol. In Vitro 2014, 28, 822-828. [CrossRef] [PubMed]

248. Levin, E.D.; Bencan, Z.; Cerutti, D.T. Anxiolytic effects of nicotine in zebrafish. Physiol. Behav. 2007, 90, 54-58. [CrossRef] [PubMed]

249. Bencan, Z.; Levin, E.D. The role of $\alpha 7$ and $\alpha 4 \beta 2$ nicotinic receptors in the nicotine-induced anxiolytic effect in zebrafish. Physiol. Behav. 2008, 95, 408-412. [CrossRef] [PubMed]

250. Levin, E.D.; Chen, E. Nicotinic involvement in memory function in zebrafish. Neurotoxicol. Teratol. 2004, 26, 731-735. [CrossRef] [PubMed]

251. Eddins, D.; Cerutti, D.; Williams, P.; Linney, E.; Levin, E.D. Zebrafish provide a sensitive model of persisting neurobehavioral effects of developmental chlorpyrifos exposure: Comparison with nicotine and pilocarpine effects and relationship to dopamine deficits. Neurotoxicol. Teratol. 2010, 32, 99-108. [CrossRef] [PubMed]

252. Yu, M.; Zhang, X.; Guo, L.; Tian, H.; Wang, W.; Ru, S. Anti-estrogenic effect of semicarbazide in female zebrafish (Danio rerio) and its potential mechanisms. Aquat. Toxicol. 2016, 170, 262-270. [CrossRef] [PubMed]

253. Roy, N.M.; Arpie, B.; Lugo, J.; Linney, E.; Levin, E.D.; Cerutti, D. Brief embryonic strychnine exposure in zebrafish causes long-term adult behavioral impairment with indications of embryonic synaptic changes. Neurotoxicol. Teratol. 2012, 34, 587-591. [CrossRef] [PubMed]

254. Wigle, D.T.; Arbuckle, T.E.; Walker, M.; Wade, M.G.; Liu, S.L.; Krewski, D. Environmental hazards: Evidence for effects on child health. J. Toxicol. Environ. Health Part B 2007, 10, 3-39. [CrossRef] [PubMed]

255. Tchounwou, P.B.; Yedjou, C.G.; Patlolla, A.K.; Sutton, D.J. Heavy metal toxicity and the environment. In Molecular, Clinical and Environmental Toxicology: Volume 3: Environmental Toxicology; Luch, A., Ed.; Springer Basel: Basel, Switzerland, 2012; pp. 133-164.

256. Depledge, M.H.; Weeks, J.M.; Bjerregaard, P. Heavy metals. In Handbook of Ecotoxicology; Blackwell Publishing Ltd.: Oxford, UK, 2009; pp. 543-569.

257. Kuhlmann, A.C.; McGlothan, J.L.; Guilarte, T.R. Developmental lead exposure causes spatial learning deficits in adult rats. Neurosci. Lett. 1997, 233, 101-104. [CrossRef]

258. Schwartz, J. Low-level lead exposure and children's IQ: A metaanalysis and search for a threshold. Environ. Res. 1994, 65, 42-55. [CrossRef] [PubMed]

259. Baghurst, P.A.; McMichael, A.J.; Wigg, N.R.; Vimpani, G.V.; Robertson, E.F.; Roberts, R.J.; Tong, S.-L. Environmental exposure to lead and children's intelligence at the age of seven years. N. Engl. J. Med. 1992, 327, 1279-1284. [CrossRef] [PubMed]

260. Joe, M.B.; Kahn, R.S.; Tanya, F.; Auinger, P.; Lanphear, B.P. Exposures to environmental toxicants and attention deficit hyperactivity disorder in U.S. Children. Environ. Health Perspect. 2006, 114, 1904-1909.

261. Lee, J.; Freeman, J.L. Embryonic exposure to $10 \mu \mathrm{g} \cdot \mathrm{L}^{-1}$ lead results in female-specific expression changes in genes associated with nervous system development and function and alzheimer's disease in aged adult zebrafish brain. Metallomics 2016, 8, 589-596. [CrossRef]

262. Richetti, S.K.; Rosemberg, D.B.; Ventura-Lima, J.; Monserrat, J.M.; Bogo, M.R.; Bonan, C.D. Acetylcholinesterase activity and antioxidant capacity of zebrafish brain is altered by heavy metal exposure. Neurotoxicology 2011, 32, 116-122. [CrossRef] [PubMed]

(C) 2016 by the authors; licensee MDPI, Basel, Switzerland. This article is an open access article distributed under the terms and conditions of the Creative Commons Attribution (CC-BY) license (http://creativecommons.org/licenses/by/4.0/). 